\title{
Mineral-Ecological Cropping Systems-A New Approach to Improve Ecosystem Services by Farming without Chemical Synthetic Plant Protection
}

\author{
Beate Zimmermann ${ }^{1, *}$, Ingrid Claß-Mahler ${ }^{1, *}$, Moritz von Cossel ${ }^{2, *} \mathbb{0}$, Iris Lewandowski ${ }^{2} \mathbb{D}$, Jan Weik ${ }^{2}$, \\ Achim Spiller $\left.^{3}{ }^{(}\right)$, Sina Nitzko ${ }^{3}{ }^{(D}$, Christian Lippert $^{4}{ }^{(D)}$, Tatjana Krimly ${ }^{4}$, Isabell Pergner ${ }^{4}$, Christian Zörb ${ }^{5}(\mathbb{D}$, \\ Monika A. Wimmer ${ }^{5}{ }^{(}$, Markus Dier ${ }^{5}$, Frank M. Schurr $\left.{ }^{6}{ }^{(}\right)$, Jörn Pagel ${ }^{6} \mathbb{D}^{\circ}$, Adriana Riemenschneider ${ }^{6} \mathbb{D}^{\circ}$, \\ Hella Kehlenbeck ${ }^{7}$, Til Feike ${ }^{7}$, , Bettina Klocke ${ }^{7}$, Robin Lieb ${ }^{7}$, Stefan Kühne ${ }^{7}$, Sandra Krengel-Horney ${ }^{7}$, \\ Julia Gitzel ${ }^{7}$, Abbas El-Hasan ${ }^{8}{ }^{\mathbb{D}}$, Stefan Thomas ${ }^{8}$, Martin Rieker ${ }^{8} \mathbb{D}$, Karl Schmid ${ }^{9}$ (D), Thilo Streck ${ }^{10} \mathbb{D}$, \\ Joachim Ingwersen ${ }^{10}$, Uwe Ludewig ${ }^{11}\left(\mathbb{D}\right.$, Günter Neumann ${ }^{11}\left(\mathbb{D}\right.$, Niels Maywald ${ }^{11}\left(\mathbb{D}\right.$, Torsten Müller ${ }^{12} \mathbb{D}$, \\ Klára Bradáčová ${ }^{12}$, Markus Göbel ${ }^{12} \mathbb{D}$, Ellen Kandeler ${ }^{13}{ }^{\mathbb{D}}$, Sven Marhan ${ }^{13} \mathbb{D}$, Romina Schuster ${ }^{13}$, \\ Hans-W. Griepentrog ${ }^{14}$, David Reiser ${ }^{14}\left(\mathbb{D}\right.$, Alexander Stana ${ }^{14}$, Simone Graeff-Hönninger ${ }^{15}$ (D), \\ Sebastian Munz ${ }^{15}$ (D) , Dina Otto ${ }^{15}$, Roland Gerhards ${ }^{16}\left(\mathbb{D}\right.$, Marcus Saile ${ }^{16}$, Wilfried Hermann ${ }^{17}$ (D), \\ Jürgen Schwarz ${ }^{7}{ }^{D}$, Markus Frank ${ }^{18}$, Michael Kruse ${ }^{19}$, Hans-Peter Piepho ${ }^{20} \mathbb{D}$, Peter Rosenkranz ${ }^{21}$, \\ Klaus Wallner ${ }^{21}$, Sabine Zikeli ${ }^{22}$, Georg Petschenka ${ }^{23}$, Nicole Schönleber ${ }^{1}$, Ralf T. Vögele ${ }^{8}$ (D) \\ and Enno Bahrs $1, * \mathbb{D}$
}

check for

updates

Citation: Zimmermann, B.;

Claß-Mahler, I.; von Cossel, M.; Lewandowski, I.; Weik, J.; Spiller, A.; Nitzko, S.; Lippert, C.; Krimly, T.;

Pergner, I.; et al. Mineral-Ecological Cropping Systems-A New

Approach to Improve Ecosystem Services by Farming without Chemical Synthetic Plant Protection. Agronomy 2021, 11, 1710. https:// doi.org/10.3390/agronomy11091710

Academic Editor: Jie Zhao

Received: 6 August 2021

Accepted: 24 August 2021

Published: 27 August 2021

Publisher's Note: MDPI stays neutral with regard to jurisdictional claims in published maps and institutional affiliations.

Copyright: (c) 2021 by the authors. Licensee MDPI, Basel, Switzerland. This article is an open access article distributed under the terms and conditions of the Creative Commons Attribution (CC BY) license (https:/ / creativecommons.org/licenses/by/ $4.0 /)$
1 Farm Management (410b), University of Hohenheim, Schwerzstr. 44, 70599 Stuttgart, Germany; nicole.schoenleber@uni-hohenheim.de

2 Biobased Resources in the Bioeconomy (340b), Institute of Crop Science, University of Hohenheim, Fruwirthstr. 23, 70599 Stuttgart, Germany; iris_lewandowski@uni-hohenheim.de (I.L.); jan.weik@uni-hohenheim.de (J.W.)

3 Marketing for Food and Agricultural Products, Department of Agricultural Economics and Rural Development, University of Göttingen, Platz der Göttinger Sieben 5, 37073 Göttingen, Germany; a.spiller@agr.uni-goettingen.de (A.S.); snitzko@uni-goettingen.de (S.N.)

4 Production Theory and Resource Economics (410a), University of Hohenheim, Schwerzstr. 44, 70599 Stuttgart, Germany; christian.lippert@uni-hohenheim.de (C.L.); t.krimly@uni-hohenheim.de (T.K.);

isabell.pergner@uni-hohenheim.de (I.P.)

5 Plant Product Quality (340e), University of Hohenheim, Emil Wolff Str. 25, 70599 Stuttgart, Germany; christian.zoerb@uni-hohenheim.de (C.Z.); m.wimmer@uni-hohenheim.de (M.A.W.); markus.dier@uni-hohenheim.de (M.D.)

6 Landscape and Plant Ecology (320a), University of Hohenheim, Ottilie-Zeller-Weg 2, 70599 Stuttgart, Germany; frank.schurr@uni-hohenheim.de (F.M.S.); joern.pagel@uni-hohenheim.de (J.P.); a.riemenschneider@uni-hohenheim.de (A.R.)

7 Julius Kühn Institute (JKI) — Federal Research Centre for Cultivated Plants, Institute for Strategies and Technology Assessment, Stahnsdorfer Damm 81, 14532 Kleinmachnow, Germany;

hella.kehlenbeck@julius-kuehn.de (H.K.); til.feike@julius-kuehn.de (T.F.); bettina.klocke@julius-kuehn.de (B.K.); Robin.Lieb@julius-kuehn.de (R.L.); stefan.kuehne@julius-kuehn.de (S.K.); sandra.krengel@julius-kuehn.de (S.K.-H.); Julia.Gitzel@julius-kuehn.de (J.G.); juergen.schwarz@julius-kuehn.de (J.S.)

8 Phytopathology (360a), Institute of Phytomedicine, University of Hohenheim, Otto-Sander-Str. 5, 70599 Stuttgart, Germany; aelhasan@uni-hohenheim.de (A.E.-H.); stefan.thomas@uni-hohenheim.de (S.T.); m.rieker@uni-hohenheim.de (M.R.); ralf.voegele@uni-hohenheim.de (R.T.V.)

9 Crop Biodiversity and Breeding Informatics (350b), University of Hohenheim, Fruwirthstr. 21, 70599 Stuttgart, Germany; karl.schmid@uni-hohenheim.de

10 Biogeophysics (310d), University of Hohenheim, Emil Wolff Str. 27, 70599 Stuttgart, Germany; thilo.streck@uni-hohenheim.de (T.S.); jingwer@uni-hohenheim.de (J.I.)

11 Nutritional Crop Physiology (340h), Institute of Crop Science, University of Hohenheim, Fruwirthstr. 20, 70599 Stuttgart, Germany; u.ludewig@uni-hohenheim.de (U.L.); gd.neumann@uni-hohenheim.de (G.N.); Niels.Maywald@uni-hohenheim.de (N.M.)

12 Fertilization and Soil Matter Dynamics (340i), University of Hohenheim, Fruwirthstr. 20, 70599 Stuttgart, Germany; torsten.mueller@uni-hohenheim.de (T.M.);

klara.bradacova@uni-hohenheim.de (K.B.); markus.goebel@uni-hohenheim.de (M.G.)

13 Soil Biology (310b), Institute of Soil Science and Land Evaluation, University of Hohenheim, Emil-Wolff-Str. 27, 70599 Stuttgart, Germany; ellen.kandeler@uni-hohenheim.de (E.K.); sven.marhan@uni-hohenheim.de (S.M.); romina.schuster@uni-hohenheim.de (R.S.) 
14 Technology in Crop Production (440d), University of Hohenheim, Garbenstr. 9, 70599 Stuttgart, Germany; hw.griepentrog@uni-hohenheim.de (H.-W.G.); david.reiser@uni-hohenheim.de (D.R.); a.stana@uni-hohenheim.de (A.S.)

15 Cropping Systems and Modelling, Institute of Crop Science, University of Hohenheim, Fruwirthstr. 23, 70599 Stuttgart, Germany; simone.graeff@uni-hohenheim.de (S.G.-H.); s.munz@uni-hohenheim.de (S.M.); dina.otto@uni-hohenheim.de (D.O.)

16 Weed Science (360b), University of Hohenheim, Otto-Sander-Str. 5, 70599 Stuttgart, Germany; roland.gerhards@uni-hohenheim.de (R.G.); marcus.saile@uni-hohenheim.de (M.S.)

17 Agricultural Experiment Station, University of Hohenheim (400), Schwerzstraße 21, 70599 Stuttgart, Germany; wilfried.hermann@uni-hohenheim.de

18 Institute of Applied Agriculture (IAAF), Nuertingen Geislingen University, Marktstr. 16, 72622 Nürtingen, Germany; markus.frank@hfwu.de

19 Seed Science and Technology (350d), University of Hohenheim, Fruwirthstr. 21, 70599 Stuttgart, Germany; michael.kruse@uni-hohenheim.de

20 Biostatistics (340c), University of Hohenheim, Fruwirthstr. 23, 70599 Stuttgart, Germany; piepho@uni-hohenheim.de

21 Apicultural State Institute, University of Hohenheim, August-von-Hartmann-Str. 13, 70599 Stuttgart, Germany; peter.rosenkranz@uni-hohenheim.de (P.R.);

klaus.wallner@uni-hohenheim.de (K.W.)

22 Center for Organic Farming (309), University of Hohenheim, Fruwirthstr. 14-16, 70599 Stuttgart, Germany; sabine.zikeli@uni-hohenheim.de

23 Applied Entomology (360c), University of Hohenheim, Otto-Sander-Str. 5, 70593 Stuttgart, Germany; georg.petschenka@uni-hohenheim.de

* Correspondence: beate.zimmermann@uni-hohenheim.de (B.Z.); ingrid.classmahler@uni-hohenheim.de (I.C.-M.); moritz.cossel@uni-hohenheim.de (M.v.C.); bahrs@uni-hohenheim.de (E.B.)

Abstract: The search for approaches to a holistic sustainable agriculture requires the development of new cropping systems that provide additional ecosystem services beyond biomass supply for food, feed, material, and energy use. The reduction of chemical synthetic plant protection products is a key instrument to protect vulnerable natural resources such as groundwater and biodiversity. Together with an optimal use of mineral fertilizer, agroecological practices, and precision agriculture technologies, a complete elimination of chemical synthetic plant protection in mineral-ecological cropping systems (MECSs) may not only improve the environmental performance of agroecosystems, but also ensure their yield performance. Therefore, the development of MECSs aims to improve the overall ecosystem services of agricultural landscapes by (i) improving the provision of regulating ecosystem services compared to conventional cropping systems and (ii) improving the supply of provisioning ecosystem services compared to organic cropping systems. In the present review, all relevant research levels and aspects of this new farming concept are outlined and discussed based on a comprehensive literature review and the ongoing research project "Agriculture 4.0 without Chemical-Synthetic Plant Protection".

Keywords: food security; pesticide-free agriculture; biological control; nutrient efficiency; resistance breeding; equidistant seeding; precision farming; life cycle assessment; sustainable intensification; agroecological intensification

\section{Introduction}

Global population growth and rising yield risks pose an increasing challenge to global food security [1-3]. At the same time, natural livelihoods are threatened by accelerated climate change, rising biodiversity loss, and increasing disruption of nutrient cycles [4]. In recent decades, agricultural cropland intensification and expansion have also led to a significant environmental degradation in many regions of the world [5-7]. The global productive agricultural area is decreasing due to numerous reasons such as urbanization, water scarcity, and soil degradation [8,9]. Furthermore, increasing competition between different land uses can be observed; for instance, between the production of biomass (food, feed, fiber, and fuel) and the provisioning of other ecosystem services [10-12]. The question 
therefore arises as to what possible solutions there are for securing the world's food supply while at the same time reducing environmental damage. In addition to reducing food waste and changing dietary habits [13-15], agriculture is challenged to develop longterm sustainable, site-appropriate cropping systems that are able to meet local and global requirements in terms of environmental protection and food security.

The aim of this review is to describe the development of a new farming concept for moderate climates that may significantly improve the environmental performance of agroecosystems while safeguarding yields and product quality. The main characteristic of this new farming concept is the complete refrainment from the use of chemical synthetic plant protection products (CSPs). The exclusion of CSPs is expected to add value to food products from this new farming concept, which may be appreciated by a growing consumer demand for ecologically sustainable products. In an appropriate price segment, this may create a bridge between established conventional and organic products, making it easier for producers and consumers to opt for more sustainable production and consumption. In view of the above, first, different agricultural farming concepts are characterized below and the need for further development is outlined. Second, the idea of new cropping systems following the new farming concept mentioned above is presented. Such new cropping systems are currently being developed and tested in field trials at several locations in Germany as part of the joint research project "Agriculture 4.0 without Chemical-Synthetic Plant Protection" [16]. These new cropping systems are referred to below as "mineralecological cropping systems" (MECSs). The cultivation measures characterizing these cropping systems focus on improving the overall ecosystem services. At the level of cultivation measures, the potential provision of ecosystem services [17-19] by the new MECSs is analyzed and compared to alternative cultivation measures applied in organic and conventional cropping systems. Expectations for these new cropping systems are discussed from economic, ecological, and social perspectives, based on literature and expert knowledge of the research consortium. This contribution is intended to stimulate further research on MECSs under varying natural and economic conditions.

\section{Characterization of Farming Concepts}

Despite the recent emergence of land-independent food production systems, such as sky farming and urban farming, future global food security will continue to rely predominantly on land-based farming systems [1]. During the past century, various forms of land cultivation have emerged that differ in numerous ways, but coexist. Basically, all farming systems can be classified as either conventional or organic. Whereas conventional farming rather focuses on maximizing yields with the help of more or less industrialized processes, organic farming is oriented toward the use of natural regulatory processes (Figure 1). Within the two basic concepts of conventional and organic agriculture, there is a broad spectrum of conventional and organic farming systems that rely to varying degrees on industrialized or natural process control. Furthermore, they often integrate different sub-concepts with a partial or holistic scope.

The main characteristics of industrialized process control are a high degree of technology and specialization, in addition to a high input of energy and external means of production (Table 1). Production processes are comprehensively controlled, for instance with the aid of synthetic fertilizers, synthetic plant protection products or genetic engineering. The most highly industrialized form entails the land-independent production of plants or animals in closed facilities with automated control of light, water, and climatic conditions. Examples of highly industrialized farming systems are maize or soybean monocultures in North and South America, palm oil plantations in Asia, and vertically highly integrated forms of animal husbandry, especially in the poultry sector, in addition to indoor growing of fruit and vegetables. Natural process control is characterized by highly diversified crop rotations and site-adapted, resistant varieties. Natural cycles are largely closed by means of on-farm nutrient production and by largely avoiding external means of production. 


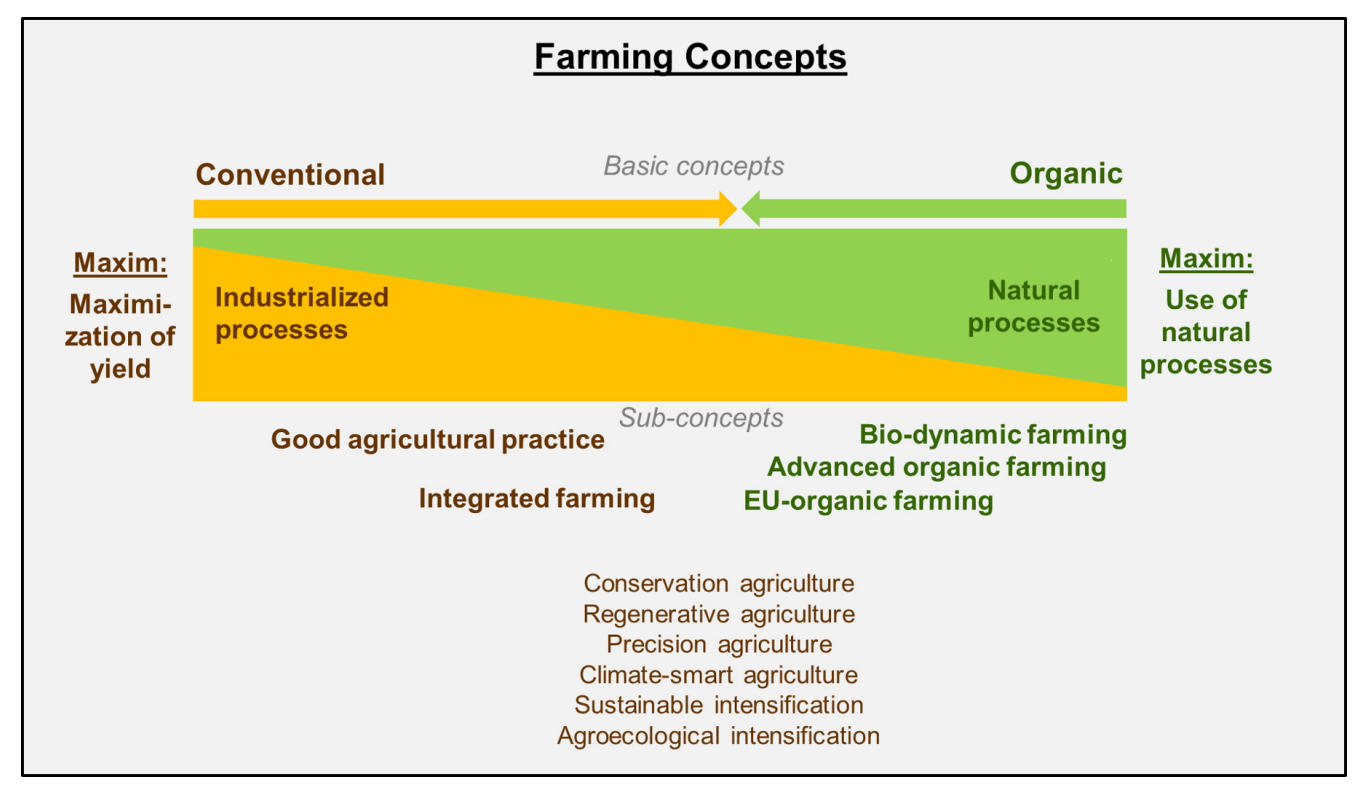

Figure 1. Schematic representation of farming concepts.

Table 1. Main characteristics of industrialized and natural process control in farming systems (modified in line with [20-23].

\begin{tabular}{llll}
\hline Industrialized Process Control & \multicolumn{2}{l}{ Natural Process Control } \\
\hline- & monotone crop rotations & - & diverse crop rotations \\
- & low degree of heterogeneity in & - & high degree of heterogeneity in \\
agricultural landscape & & $\begin{array}{l}\text { agricultural landscape } \\
\text { site-adapted, resistant varieties }\end{array}$ \\
- & high-yield varieties & - & low external inputs \\
- & high external inputs & - & towards closed cycles \\
- & open cycles & - & low capital intensity \\
- & high capital intensity & - & high labor intensity \\
- & low labor intensity & - & low degree of mechanization \\
- & high degree of mechanization & - & low degree of specialization \\
- & high degree of specialization & - & covers a large part of the value chain \\
- & high vertical integration & - & higher use of natural regulatory \\
- & comprehensive control of agricultural & processes for agricultural production \\
\hline
\end{tabular}

In their extreme forms, these two concepts of process control are only realized in a small proportion of farming systems. With regard to conventional and organic cropping systems, their characteristics are manifold and an increasing blending of the two approaches to process control can be observed. Specialized, highly technical arable farms are increasingly integrating measures to promote environmental sustainability, such as landscape elements, precision farming, and eco-schemes [24,25]. In organic farms, elements of industrialized process control, such as an increasing degree of mechanization and specialization, in addition to trends toward global processing and marketing structures, can be observed [26,27]. Examples include organic strawberry and grape monocultures with increasing input dependence in California [23,26], and rather industrially produced and marketed organic products, which are perceived as "organic-light" [28,29]. However, holistic sustainable farming systems not only fulfill defined minimum standards, e.g., by omitting chemical pesticides and synthetic fertilizers ("substitution approach"). They integrate ecological, social and cultural sustainability aspects [27,30,31], e.g., by promoting heterogeneous agricultural land [22,23] and regional value chains [29]. A truly sustainable agriculture is also demanded by "Organic 3.0", a vision of the global organic movement [27]. 
Globally, conventional farming systems account for the largest share of agricultural production and land use. Organic agriculture amounts to only $1.5 \%$ globally, but $7.7 \%$ in the EU and 9.1\% in Germany with a growing tendency [32]. Within conventional farming, progress towards more sustainable farming systems can be observed. Globally, an estimated $29 \%$ of all farms practice sustainable intensification methods, such as integrated farming or conservation agriculture, on $9 \%$ of farmland [24]. Within the EU, conventional farming is based on the standard of "Good Agricultural Practice", which is defined by legally regulated minimum requirements. These relate to the use of plant protection products [33] or health management in animal husbandry. A further reduction or minimization of ecological and health risks is the goal of "Integrated Farming" [34]. "Integrated Farming" uses both chemical and organic inputs for nutrient supply and plant protection, but use is based on economic thresholds for damage. It takes advantage of the natural strengths of plants, such as resistance to drought or disease. An important pillar of integrated farming is "Integrated Pest Management" [33], which has been mandatory in the EU since January 2014. The characteristics of organic agriculture [30] range from the more pragmatically oriented EU regulations for organic agriculture [35] to anthroposophically oriented biodynamic agriculture [36]. Overall, there are several organic farming associations that defined advanced sub-concepts of organic farming including higher standards compared to EU regulations $[37,38]$.

Within these sub-concepts of conventional and organic farming systems, there are multiple approaches to increase ecological or economic sustainability. These approaches are either process oriented or result oriented. They focus on individual cultivation measures, on the use of specific technologies, or on particular ecological or economic goals. Additionally, they may take into account partial aspects, the entire cropping system, or even the entire food sector. All these approaches to the optimization of farming systems focus on the preservation of natural resources and the promotion of ecological or economic sustainability. "Conservation Agriculture" aims to maintain and enhance soil fertility through reduced tillage, year-round greening, and diversification of varieties and crop rotations [39]. The main goals of "Regenerative Agriculture" are to build up humus, improve soil health, increase biodiversity, and promote plant-soil interactions. Key farming practices include eliminating or minimizing tillage, permanent greening, and organic fertilization [40]. "Precision Agriculture" seeks to minimize agricultural inputs by applying plant- and site-specific crop management using modern agricultural technologies, including digitization [41].

More holistic approaches to achieve global food and environmental goals underlie the concepts of "Sustainable Intensification" and "Agroecological Intensification". The overall objective of "Sustainable Intensification" is to achieve a yield increase without taking up additional land or harming the environment. It is relatively open and does not privilege any particular vision or method of agricultural production [42-44]. It focuses on increasing resource efficiency, including the use of technology [45]. "Sustainable Intensification" is guided by the concept of "land sparing" to preserve natural landscapes. "Agroecological Intensification" is more explicitly defined and focuses on understanding, strengthening and using biological and ecological processes by applying multiple agroecological practices $[44,46]$. Agroecological approaches connect scientific ecological disciplines and farm management $[26,43]$. This is because healthy ecosystems provide a range of services that help to maintain yield stability, pest and pathogen control, nutrient cycling, and resilience. Biodiversity plays a key role in this [42]. "Agroecological Intensification" is based on the concept of "land sharing" [45]. The implementation of agroecological approaches necessitates a fundamental redesign of farming systems considering both participatory approaches and adaptation to local conditions [26,31,42]. Climate-Smart Agriculture is an integrated management approach that addresses the interlinked challenges of food security and accelerated climate change [47,48]. Climate-Smart Agriculture is based on the concept of "Sustainable Intensification" [49]. The Climate-Smart Agriculture approach pursues three objectives: sustainably increasing productivity and incomes, adapting to climate 
change, and reducing greenhouse gas emissions [39]. The measures used to achieve these goals are highly variable [47]. "Climate-Smart Agriculture is not a set of practices that can be universally applied, but rather an approach that involves different elements embedded in local contexts" [39]. Overall, there is an ongoing contrasting debate about whether high technology-based or ecology-based practices are the most appropriate agricultural production practices to achieve the goal of higher yet sustainable food production [46].

Examples of private initiatives show how such approaches to improve sustainability of cropping systems can be implemented at a local level. In southern Germany, marketing communities such as "KraichgauKorn" [50] and "BlütenKORN" [51] are associations of farmers, mills, and bakeries that commit to specific cultivation measures to provide particular ecosystem services. They define guidelines for the entire value chain and add value to the ecosystem services they provide by placing appropriately labeled products on the market. A further example of a farmer's association producing and marketing more sustainable food products is "IP-Suisse" [52].

Studies on the ecosystem services of different farming systems are often based on comparisons between conventional and organic farming. Thus, numerous studies confirm that organic farming provides higher-regulating ecosystem services than conventional farming [14,53-58]. This is especially true for area-based considerations, which are normally taken as the reference for ecosystem services. In terms of output-related environmental efficiency, conventional agriculture performs better in most studies because of higher yields $[57,59,60]$. Numerous meta-studies show that yields are lower in organic farming than in conventional farming, due to nutrient deficiencies, damage from diseases, pests, or weeds. The average yield gaps range from 19 to $25 \%$ for all crops studied globally [57,58,61-63]. There are major differences between individual sites, crops, and specific cultivation methods [57,63]. For example, the yield gap of up to $40 \%$ for wheat and barley is above average, whereas for maize it is below average at around 15\% [63]. Furthermore, it can be seen that the yield gap widens in some cases with increasing yields in conventional cultivation [62]. In Germany, the yield gap is up to $45 \%$ [14] or 50\% [64]. When comparing the results of the Federal Ministry of Food and Agriculture (BMEL) farm network, yield differences of up to 50\% are discernible depending on crop and year [64]. According to Treu et al. [65], organic farming in Germany requires 45\% more land than conventional farming, even assuming reduced meat consumption and thus a lower land requirement. Overall, the reported yield gap tends to underestimate the actual yield difference in most studies by making comparisons at the crop level. Therefore, De Ponti et al. [62] call for an accurate productivity analysis of organic and conventional practices at a higher system level. This is intended to help adequately account for specific nutrient availability when organic farms (i) have additional rotations with nutrient-accumulating crops or (ii) use farm manure across farms.

Overall, however, it is the individual cultivation measures that produce specific ecosystem services, rather than the conventional or organic orientation of a cropping system. These include, for example, crop rotation and the type of fertilization, crop protection, or soil cultivation $[55,57,59]$. Thus, agricultural cropping systems are mainly characterized by the composition of their underlying cultivation practices. The optimization of cropping systems in terms of related ecosystem services therefore seems most feasible at the level of cultivation measures (Table 2). In addition, site factors such as landscape structure, which are important determinants of biodiversity regardless of cropping practices, determine the level of ecosystem services provided by agricultural landscapes $[54,56,66,67]$.

\section{Implications for the Further Development of Agricultural Cropping Systems}

Different cropping systems provide different ecosystem services (provisioning, regulating, habitat, and cultural services $[17,18])$. Due to multiple trade-offs, individual ecosystem services of a cropping system cannot be maximized simultaneously. An increase in yield often leads to a decrease in regulating services and vice versa [68]. Therefore, the merits of different cropping systems cannot be assessed in general terms, but must always be 
considered in the context of local or global requirements for individual ecosystem services $[39,69]$. For example, certain mandatory local environmental requirements, such as groundwater or biodiversity protection, may justify very extensive cropping systems that provide lower yields, but a high level of regulating ecosystem services. Conversely, global food security and environmental goals may justify more intensive cropping systems that deliver higher yields and, in some cases, higher environmental efficiency, especially when land-use change effects are taken into account. Overall, the major challenge of agroecosystem management is to promote multiple ecosystem services in a manner that enhances their global provisioning by reducing trade-offs and increasing synergies [68,70,71]. In this context, numerous studies have concluded that there is no single optimal cropping system and that existing cropping systems must evolve $[39,57,59]$. If organic farming is to secure the world's food supply, yields must be increased significantly without causing additional harm to the environment $[14,15,57,59]$. The main challenges here are nutrient deficiencies, diseases, and pest and weed infestation. In contrast, for conventional farming systems, a reduction of chemical pesticide and fertilizer input, and their emissions, constitutes the greatest challenge when it comes to reducing damage to the environment [57]. To complement the intensification of organic agriculture and the greening of conventional agriculture $[14,15,66]$, there are recommendations to remove the sharp boundaries between organic and conventional farming by developing "hybrid" farming systems that combine different technologies and farming practices from organic and conventional agriculture [63]. These hybrid farming systems already exist in many forms (Figure 1).

In general, the question arises regarding how the global food supply can be secured in the future [11]. In principle, an expansion of agricultural land, yield increases, a more efficient use of food and a change in human diets can contribute to improving the world's food supply. According to Niggli and Riedel [15], even an expansion of organic farming is feasible if food waste is reduced and animal-based foods in the human diet are partially replaced by plant-based foods that require less land. However, as long as there is no significant global change in dietary structure and no increased efficiency in food utilization, organic farming will only be able to make a limited contribution to global food security due to its lower productivity $[63,72]$. Conventional farming causes severe damage to ecosystems in some cases. The numerous hybrid farming concepts often demonstrate only minor ecological advantages. Furthermore, apart from a few local initiatives, they rarely succeed in placing a clearly distinguishable product with ecological valorization options on the market.

At the political level, the aim is also to develop environmentally friendly agricultural farming systems. As part of the EU's Green Deal, the EU Commission has formulated goals for the future direction of agriculture in the EU in its Farm to Fork strategy. The main pillars are a reduction in the use of synthetic chemical pesticides and of nutrient losses by at least $50 \%$ by the year 2030 [73]. In this context, the European research alliance "Towards a chemical pesticide free agriculture" was formed in 2020 [74]. Its aim is to create a roadmap for the development of European agriculture towards agriculture without any chemical pesticides [74]. Within the framework of the EU, in addition to at the national and regional level, various regulations and support programs have been established to promote environmentally friendly agriculture. According to the EU Framework Directive on the sustainable use of CSPs [75], all Member States have implemented National Action Plans (NAP) to reduce risks and impacts of pesticide use on human health and the environment. As part of the French NAP "Ecophyto" [76], a network of farmers has been established to test and evaluate possibilities for the reduction of chemical pesticide use [77]. The concern of reducing chemical pesticide use is also reflected in the EU framework for the Common Agricultural Policy (CAP) period 2023-2026. Here, the German strategy plan for the upcoming EU CAP period foresees the promotion of the abandonment of chemical pesticide use as a possible measure within the eco-schemes [78]. In addition, the "Insect Protection Action Program" restricts the application of CSPs at the national level in Germany [79]. At the local level, e.g., in the state of Baden Württemberg, the 
reduction of chemical pesticide use and the conversion to organic farming is promoted by the "Biodiversity Enhancement Act" [80].

\section{Development of Mineral-Ecological Cropping Systems}

The idea of mineral-ecological farming is to establish a new farming concept apart from conventional and organic farming that is appropriate to meet both future environmental and global food requirements (Figure 2). In MECSs, in accordance with [35] and in conjunction with [81], the use of CSPs must be completely avoided. At the same time, all yield-relevant cultivation measures are to be optimized to safeguard yields. In the design of this new cropping system, new and existing technologies are combined with agroecological practices [26] to promote natural regulatory processes, and to also optimize mineral fertilization and non-chemical curative crop protection. This aims at improving the overall ecosystem services of agricultural landscapes based on (i) improved provision of regulating ecosystem services compared to conventional cropping systems and (ii) improved supply of provisioning ecosystem services compared to organic cropping systems.

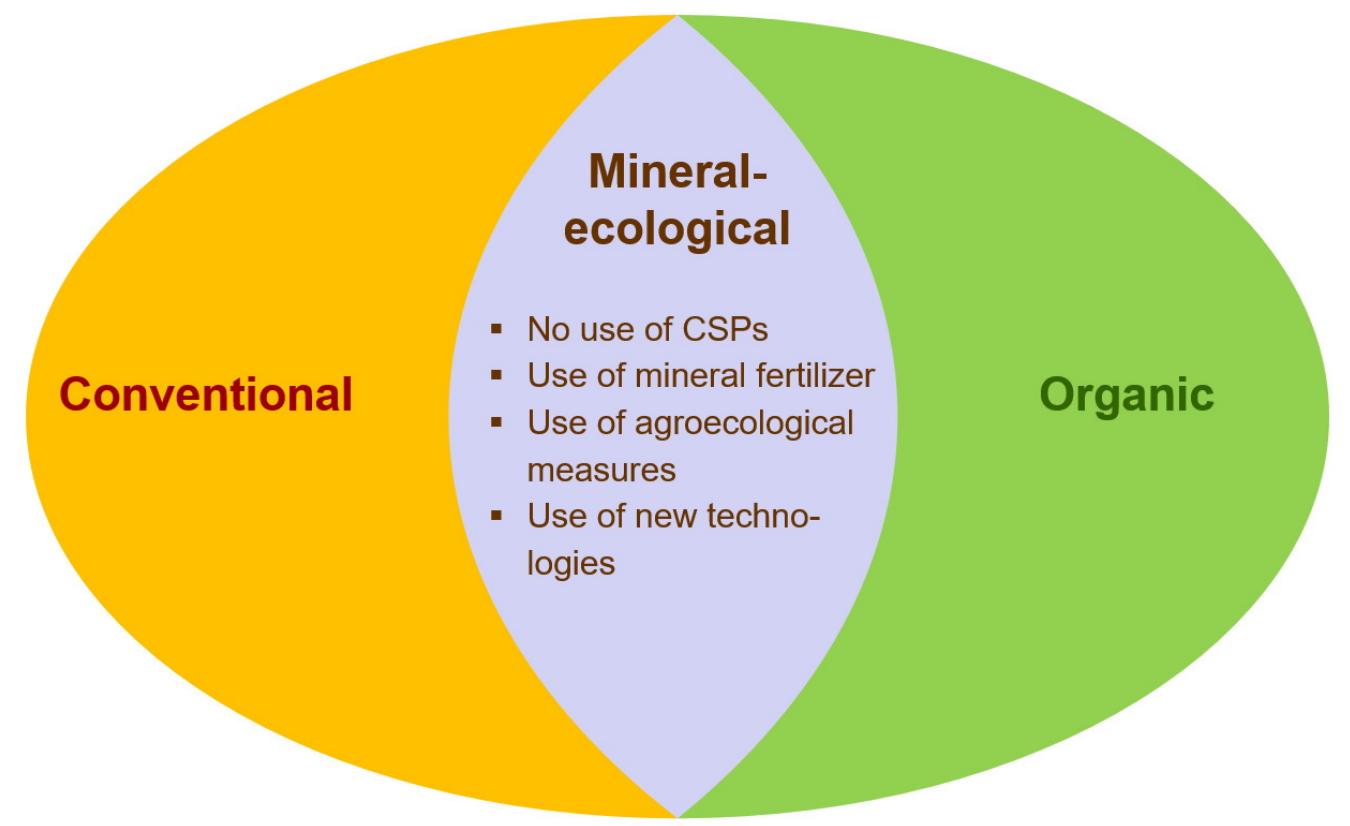

Figure 2. Complementing conventional and organic farming by mineral-ecological farming (CSPs: Chemical synthetic plant protection products).

The design, implementation, and evaluation of MECSs need to take into account various aspects at different levels (Figure 3). Multi-year system field trials are needed to capture crop rotation and long-term effects of cropping systems. Only a holistic approach will allow an adequate comparison of MECSs with conventional and organic cropping systems. This includes studies at the farm, regional, processor, and consumer levels with respect to success criteria and possible adaptations. Finally, MECSs and their contribution to improved ecosystem services in comparison to conventional cropping systems needs to be evaluated. In the following, various key aspects of MECSs (Figure 3) based on both scientific literature and the approach of the project "Agriculture 4.0 without ChemicalSynthetic Plant Protection" are outlined and discussed. 


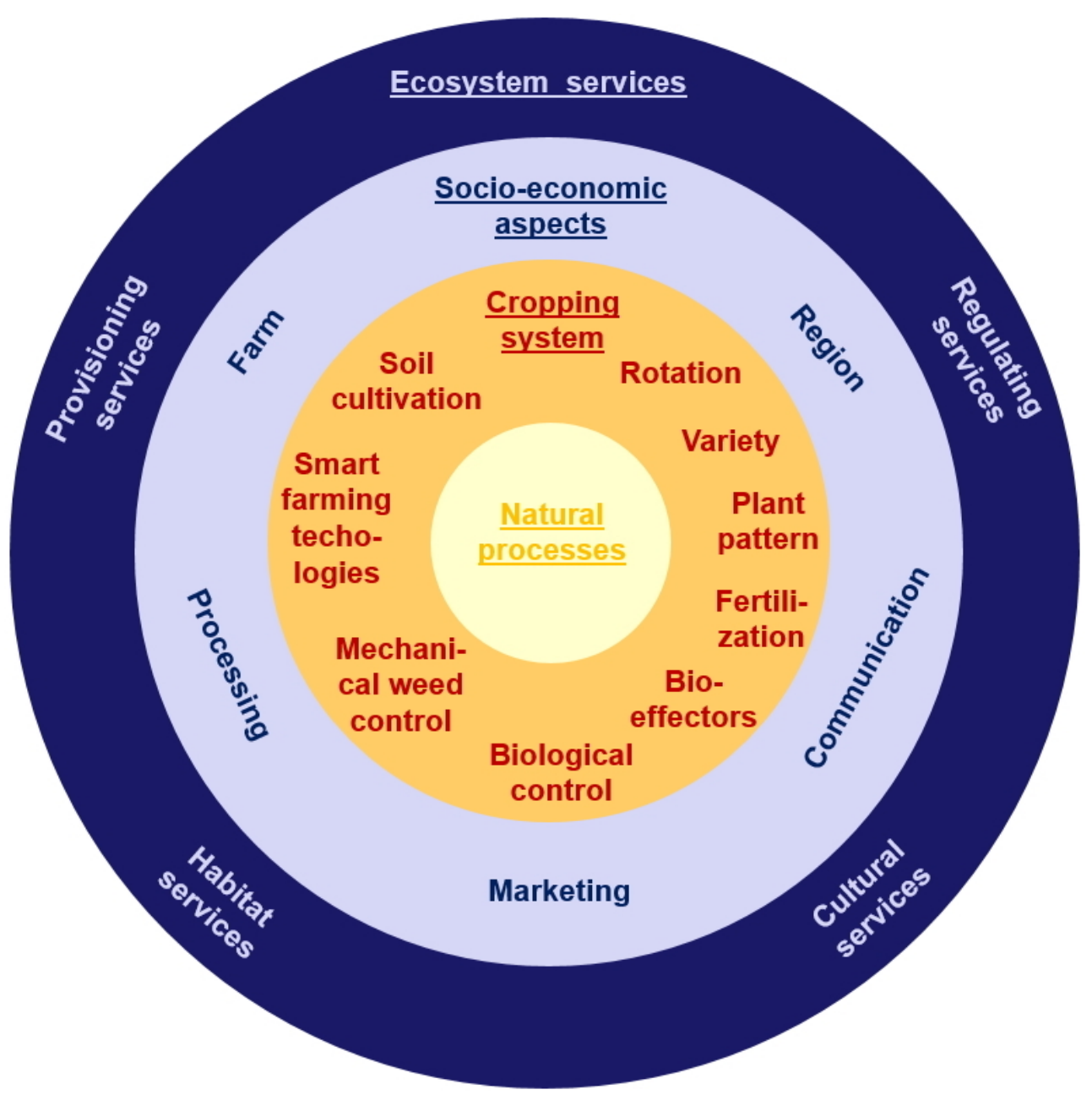

Figure 3. Schematic representation of essential levels and aspects to be considered in the development, implementation, and evaluation of mineral-ecological cropping systems.

\subsection{Exclusion of Chemical Synthetic Plant Protection Products in Mineral-Ecological Cropping Systems}

Refraining from CSPs is a key tool in MECSs for improving numerous ecosystem services (Table 2). In particular, positive effects on biodiversity, pollination, biological control, soil fertility, and climate regulation can be expected. Furthermore, increasing biodiversity may have positive effects on the cultural services of agricultural landscapes. However, yield losses due to disease and weed or pest infestation can affect regulating services, such as reduced nutrient efficiency [82], and thus lead to nutrient leaching, i.e., negative effects on nutrient cycles and water quality. Nonetheless, a reduction of the active ingredient contamination of water bodies can be expected by refraining from the use of CSPs [83]. In addition to reduced pesticide exposure, increased pathogen exposure is expected, leading to quality degradation and health hazards. A problem related to fungal diseases is the production of mycotoxins and, in particular, those produced by $F$. graminearum pose a risk for humans and livestock because they can cause poisoning and fertility and growth disorders [84-86]. Overall, the abandonment of chemical pesticides is expected to have predominantly positive effects in terms of regulating habitat, and cultural services, but at the same time, provisioning services are expected to be significantly impaired in terms of yield levels and yield stability $[31,87,88]$.

Scientific evidence on yield effects associated with the absence of CSPs in MECSs is very limited. Although the yield differences between organic and conventional cropping systems have been investigated in numerous studies, it is not known to what extent the lower yields in organic farming are due to the absence of CSPs or to other factors. There 
is only fragmentary knowledge on the consequences of not using CSPs. This knowledge either builds on data from individual sites $[87,89,90]$, only considers individual ecosystem services, primarily yield [91,92], or merely removes CSPs from the system without making further adjustments to the cropping system [88,93]. A detailed analysis of the factors influencing yield formation is a central pillar in the development of MECSs. In this regard, it is crucial to assess and develop optimal combinations of cultivation measures in order to keep yield and quality losses as low as possible while dispensing with CSPs [94].

\subsection{Mineral-Ecological Cropping Systems from a Production Technology Perspective}

When CSPs are excluded, the yield performance of agricultural cropping systems can be improved through a variety of agroecological and technical measures [26]. In this context, the development of MECSs focuses on optimizing all yield-relevant cultivation measures to manage the absence of CSPs. This includes both direct and indirect yield-impacting measures, and mixed forms designed to provide a wide range of ecosystem services (Table 2). The ecosystem services of individual cultivation measures, and of bundles of measures, are very complex and there are numerous interactions and trade-offs that cannot be fully explored in this review. Therefore, Table 2 only lists essential ecosystem services that are expected in connection with MECSs cultivation measures and that are described in the literature. A large number of these cultivation measures benefit from the use of precision agriculture technologies. A wide range of existing and new technologies can be applied, investigated, and further developed according to the specific requirements of the MECSs (Table 3). Indirect yield-impacting measures encompass all cultivation measures that promote natural regulatory processes, such as diverse crop rotation, the use of site-adapted, resistant varieties, and an optimal spatial distribution of plants in the field, for instance, in the form of equidistant seeding. All of these agroecological measures are intended to improve numerous regulating and habitat services, thereby helping to minimize yield fluctuations and losses. In organic cropping systems, for example, yields can be enhanced by optimizing cultivation methods, such as cultivation of mixed crops and diversification of crop rotations [61]. Biodiversity-enhancing measures, such as the promotion of diverse agroecosystems and structurally rich agricultural landscapes, lead to an improvement in many regulating services (pest regulation, pollination, and nutrient cycling), and thus to positive complementary or synergistic effects on crop yields [95-97]. Furthermore, improving soil fertility promotes plant growth and yield formation (provisioning services), and regulates diseases and pests (regulating services) [66]. In addition to agroecological cultivation measures, optimized mineral fertilization with macro- and micronutrients is a key measure to directly promote yield performance in MECSs. As nitrogen is applied as placed, stabilized ammonium, it is expected to generate positive effects on numerous regulating services compared to conventional fertilization (Table 2). Micronutrients and bioeffectors can positively influence yield performance both directly and indirectly through their plant-strengthening action. Furthermore, mechanical and biological methods of curative plant protection with different effects on regulating services are well-known cultivation measures for weed, pest, and pathogen control that directly influence yield (Table 2). 
Table 2. Expected ecosystem services ${ }^{a}$ of the main cultivation measures applied in MECSs ${ }^{b}$ (+: positive effect expected; -: negative effect expected; o: no clear effect expected).

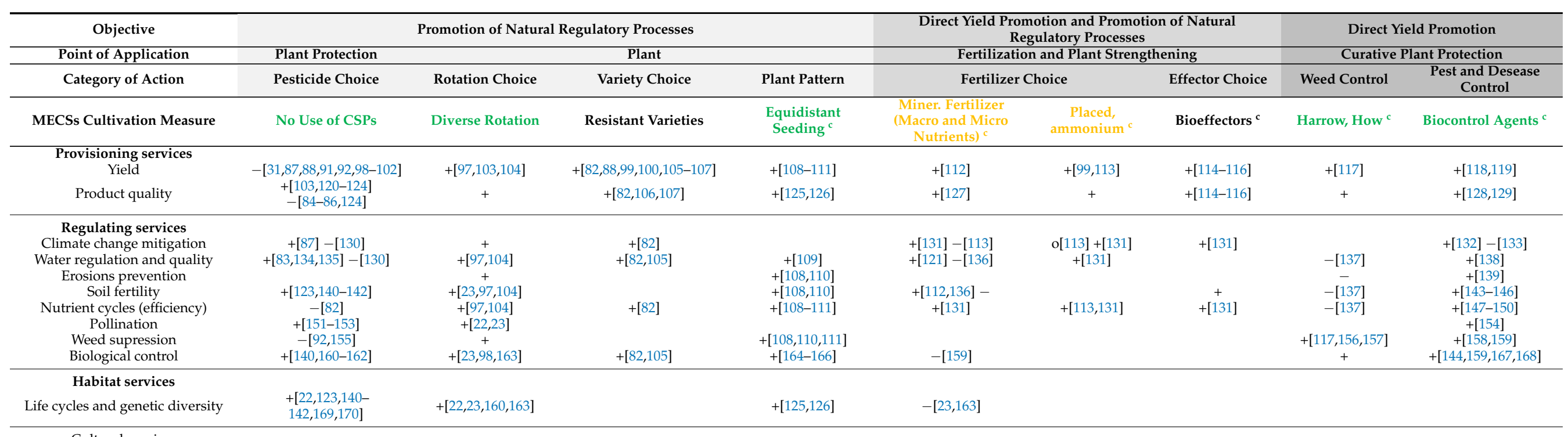

Cultural services
Recreation and tourism

$+$

$+[171]$

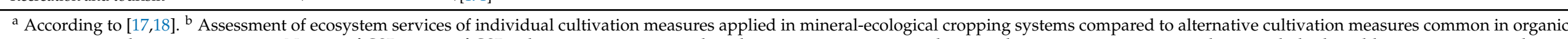

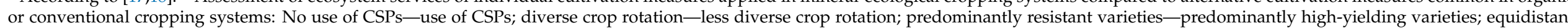

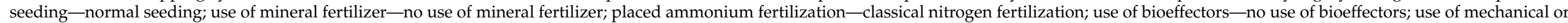

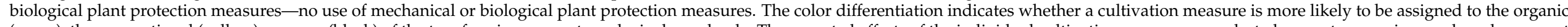

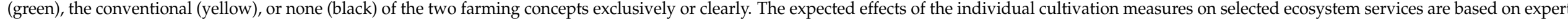

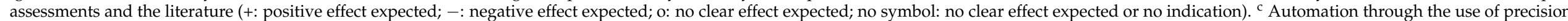
agriculture technologies enables the optimal implementation of these cultivation measures. 
Table 3. Precision agriculture technologies suitable for mineral-ecological cropping systems (MECSs).

\begin{tabular}{|c|c|c|c|c|c|}
\hline \multirow{2}{*}{ Area of Application } & \multirow{2}{*}{ Seeding } & \multirow{2}{*}{ Fertilization } & \multicolumn{3}{|c|}{ Plant Protection } \\
\hline & & & Weed Control & Desease Monitoring & Desease Control \\
\hline $\begin{array}{l}\text { Precision Agriculture } \\
\text { Technology }\end{array}$ & $\begin{array}{l}\text { A sowing unit is mounted on a } \\
\text { mobile robot platform [172]. The } \\
\text { robot uses different sensors to } \\
\text { navigate autonomously and to adapt } \\
\text { the sowing parameters to the actual } \\
\text { soil conditions [172] and } \\
\text { crop requirements. }\end{array}$ & $\begin{array}{l}\text { The modified sowing unit can be } \\
\text { used for insoil fertilization. The robot } \\
\text { uses image-based row recognition to } \\
\text { precisely place the fertilizer between } \\
\text { the crop rows [173]. }\end{array}$ & $\begin{array}{l}\text { A real-time camera-based automatic } \\
\text { guidance system is used to steer } \\
\text { hoeing blades in the center between } \\
\text { the crop row }[174,175] .\end{array}$ & $\begin{array}{c}\text { Unmanned aerial vehicles (UAVs) are combined } \\
\text { with hyperspectral imaging sensors to analyse the } \\
\text { plants spectral signature for pathogen detection } \\
\text { [176-178]. Machine learning and AI are used to } \\
\text { analyse sensor data, allowing automatic detection } \\
\text { and detection of subtle changes in early stages of } \\
\text { pathogen development [179]. }\end{array}$ & $\begin{array}{l}\text { UAVs are used for the application of } \\
\text { biological control agents (BCAs). } \\
\text { UAV-application can easily schedule } \\
\text { the release of BCAs exactly when and } \\
\text { where they are needed according to } \\
\text { their modes of action for better } \\
\text { control of plant pathogens [180]. }\end{array}$ \\
\hline $\begin{array}{l}\text { Research focus to } \\
\text { optimize cultivation } \\
\text { measures in MECSs }\end{array}$ & $\begin{array}{l}\text { - Investigation and modification of } \\
\text { technology to improve quality of } \\
\text { incorporation of seeds into soils. }\end{array}$ & $\begin{array}{l}\text { - Investigation of effectiveness and } \\
\text { efficiency of in soil fertilization } \\
\text { during vegetation period in grains. } \\
\text { • Site-specific and individual } \\
\text { plant-adapted fertilization by } \\
\text { variable rate technology. }\end{array}$ & $\begin{array}{l}\text { - Accuracy of steering and efficacy of } \\
\text { weed control by camera-guided } \\
\text { inter-row hoeing. } \\
\text { - Crop response and crop yield in } \\
\text { cereals, soybean, and maize with } \\
\text { different row spacings, growth stages, } \\
\text { driving speeds and hoeing elements. }\end{array}$ & $\begin{array}{l}\text { - Mapping of problematic areas in the field for } \\
\text { precision farming. } \\
\text { • Refinement of forecast methods. } \\
\text { - Objective assessment of disease severity and } \\
\text { plant development in MECSs. }\end{array}$ & $\begin{array}{l}\text { - Effective BCAs with al-ready } \\
\text { elucidated modes of action will be } \\
\text { evaluated under field conditions. } \\
\text { - Investigation of different } \\
\text { application schemes to establish } \\
\text { BCAs in the field according to } \\
\text { monitored forecast results. }\end{array}$ \\
\hline Expected benefits & $\begin{array}{l}\text { - Higher field emergence with } \\
\text { less seeds. } \\
\text { - More even seeding depth and soil } \\
\text { coverage of seeds. } \\
\text { - More even spatial crop plant } \\
\text { distribution according to site and } \\
\text { variety-based requirements. } \\
\text { - Better aeration of crop plant stands } \\
\text { and equal access of plants } \\
\text { to resources. } \\
\text { - Quality over quantity through } \\
\text { autonomous work. }\end{array}$ & $\begin{array}{l}\text { - Better access of crop plants to micro- } \\
\text { and macronutrients, and bioeffectors. } \\
\text { • Optimize fertilizer use and } \\
\text { minimize losses. } \\
\text { - Improving nutrient use efficiency. }\end{array}$ & $\begin{array}{l}\text { - Higher weed control efficacy. } \\
\text { - Less crop damage due to } \\
\text { higher selectivity. } \\
\text { - Higher labor efficiency due to } \\
\text { higher driving speeds. }\end{array}$ & $\begin{array}{l}\text { - Early and precise detection of disease symptoms } \\
\text { and abiotic stress factors. } \\
\text { - Assessment of disease severity and identification } \\
\text { of disease species through specific changes within } \\
\text { the plants spectral signature. } \\
\text { - Drone-based measurements permit high } \\
\text { throughput coupled with variable resolution. } \\
\text { - Automated and objective data assessment } \\
\text { through data analysis methods. }\end{array}$ & $\begin{array}{l}\text { - Drone-based biocontrol offers a } \\
\text { new tool for effective and sustainable } \\
\text { control of plant diseases. } \\
\text { - Minimizing yield losses } \\
\text { quantitatively and qualitatively } \\
\text { through combating pathogen } \\
\text { infestation and minimize the risk of } \\
\text { food safety hazards } \\
\text { (e.g., mycotoxins). }\end{array}$ \\
\hline
\end{tabular}




\subsubsection{Cultivation Measures to Promote Natural Regulatory Processes}

Cultivation measures that promote natural regulatory processes are one focus of MECSs (Table 2). These include among other measures diversified crop rotations, the use of site-adapted resistant varieties, and optimized plant distribution in the field.

Given the numerous options for process control, tight crop rotations based on the most competitive crops are possible in conventional cropping systems. Without CSPs, diversification of crop rotations is one means of reducing weed, disease, and pest pressure. Diverse crop rotations promote pest regulation, soil fertility, and biodiversity [23] (Table 2). MECSs also prioritize the most competitive crops, but combine them with less competitive ones, including catch crops that provide diverse ecological services in return. Compared to organic farming, MECSs have the great advantage of not relying on legumes for nitrogen supply. To implement preventive plant protection, to promote soil fertility, and to optimize nutrient cycles and natural regulatory processes, MECSs are dependent on the diverse, resilient crop rotation of cereals and leaf crops, winter and spring crops, and main and catch crops. Conventional crop rotations of corn and winter cereals must be widened by integrating summer cereals, protein crops, and catch crops. Although legumes are less important in MECSs than in organic farming, they may be worth being integrated in terms of delivering multiple ecosystem services, such as climate change mitigation and improvement of soil fertility, nutrient cycles, water quality, biocontrol, and habitat and cultural services [181]. It is necessary to consider not only individual crops, but also entire crop rotations, because the crop rotation effects of different pre-crop-post-crop combinations must be quantified and evaluated [182]. This must be undertaken based on long-term field trials, which identify the effects of different crop rotation combinations on yield and further ecosystem services [183].

In the absence of CSPs, the breeding of resistant varieties is of particular importance to increase resilience in MECSs and positively influence yields. For a long time, resistance breeding has played a central and successful role in the development of varieties for conventional cropping systems. Therefore, not only yield, quality, and marketing opportunities, but also resistances against multiple pathogens are key factors in the legal protection of varieties and their selection for cultivation [184]. Winter wheat varieties released in Germany are good examples, because the observed yield increase over past decades also resulted from, among other factors, strongly improved pathogen resistance [88,100]. Cultivation systems without CSPs require the perpetual development of varieties with durable resistances against multiple pathogens [185]. Multi-resistant varieties are mainly developed by marker-assisted introgression of different resistance genes (pyramiding), which will be complemented in the near future by targeted genome editing of novel resistance alleles [186-188]. A second component are improved systems for the selection of resistant varieties by combining digital tools for pathogen monitoring and real-time resistance breeding (e.g., by genome editing). Such systems aim to slow the co-evolution of pathogens with their crop hosts by increasing the diversity of resistance genes in cultivated varieties at a geographic scale. A proof of concept is the rice and rice blast pathosystem in Asia [189,190]. It demonstrates the potential and future contribution of resistance breeding to refrain from CSPs while maintaining high yield levels.

In addition to crop rotation and cultivar resistance to pathogens and pests, stand conditions of crops are of crucial importance to reduce the risk of infection and weed pressure in arable farming. Accordingly, the optimization of the spatial distribution of cultivated plants in MECSs plays a central role. Depending on the sowing pattern, variety characteristics, and crop management, different crop development and crop architecture (temporal and spatial development of the crops) will emerge. This influences not only light and nutrient conditions of the crop, but also the microclimate (water availability, temperature, and humidity dynamics) and thus weed, pest, and disease pressure, in addition to yield formation. Plants are often not optimally distributed spatially in the field $[110,191]$. As a result, plants within a crop stand have different degrees of access to required resources. Therefore, their individual development will vary accordingly. Plants 
evenly distributed in the field can make better use of their potential and resources, and are also more solidly anchored in the soil. This has advantages for mechanical weed control measures, such as harrowing. Uniform plant distribution is achieved with so-called equidistant seeding. This is expected to achieve stronger weed suppression [108], and provide a better microclimate with a lower risk of infection by fungal pathogens $[166,192]$. At the same time, it is expected to optimize potential yield and nutrient efficiency, thus leading to optimal use of mineral fertilizer. In addition to positive effects on soil erosion and soil water balance, equidistant plant distribution is expected to lead to earlier crop closure [110]. In response to spatial plant distribution, plant species or even cultivars develop different phenotypes (plasticity) [193]. Both plasticity and morphology are mainly influenced by light quality, specifically the red:far-red ratio (RFR), especially during early growth stages [194,195]. In equidistant seeding, the change in photosynthetically active radiation (PAR) and RFR is expected to increase the number of branches in soybean and the number of cobs per plant in maize. The altered plant architecture and more even distribution of plants leads to increased competitiveness for light with weeds $[125,126]$. The complex interactions (light, competition, plant architecture, and physiology) in the crop, in addition to changes in crop management (variety and seeding pattern), can be depicted in functional-structural plant models (FSPM) [196].

To assess the impact of crop architecture on pathogen establishment, microclimate measurements can be combined with numerical simulations using 3D CFD (Computational Fluid Dynamics). The change in microclimate by equidistant seeding may mitigate the risk of infection. How much the crop warms up or how fast it dries after rainfall largely depends on aerodynamic properties such as displacement height and roughness length. These, in turn, are determined by factors such as seeding density, seeding pattern, leaf area, leaf width, leaf inclination, and the variability of growth height [165]. The aerodynamics in and above the crop canopy are seen to be a crucial control to reduce disease pressure from fungal diseases. The key factor is the turbulent mixing in the upper canopy layers. Flow simulations using a virtual wind tunnel can help in investigation of the fine structure of the turbulent exchange in the crop canopy and the adjacent parts of the atmospheric surface layer. This data can be used in the NoahMP Grecos plant growth and land surface model [164] to simulate crop temperature and humidity dynamics, and estimate the risk of infestation for altered spatial plant distribution.

\subsubsection{Cultivation Measures for Direct Yield Increase, Plant Strengthening, and Plant Protection}

Cultivation measures that indirectly support yield formation by promoting natural regulatory processes need to be complemented by direct measures for yield enhancement, plant strengthening, and plant protection, such as optimized mineral fertilization in combination with bioeffectors and micronutrients, mechanical weed control, and biological pest and disease control.

To achieve similar yield levels in MECSs compared to those of conventional cropping systems, optimal nutrient application is essential. In addition, the possibilities of nutrient combinations must be optimized because they can act prophylactically against fungal, bacterial, and animal pests through infestation-suppressing and resistance-increasing effects. Moreover, essential and beneficial plant nutrients, such as silicon ( $\mathrm{Si})$, zinc (Zn), and manganese $(\mathrm{Mn})$, with proven protective effects against abiotic and biotic stress factors [197-199], in addition to plant growth-promoting bioeffectors (microorganisms and natural compounds such as algal extracts), can be applied by means of inoculation and mineral fertilization. In this context, continued development and selective use of ammonium depots (e.g., with the Cultan technique or the use of fertilizers stabilized by means of nitrification inhibitors using in-soil fertilization), in addition to targeted application of calcium cyanamide, bioeffectors, and micronutrients with adapted soil and foliar applications, is relevant. In addition to providing adequate nutrient supply and protective functions, these measures are used to ensure optimal nutrient balances. In contrast to organic fertilizers, individual mineral nutrients can be applied in a targeted, plant-available form as needed, 
and some forms of nitrogen also have a certain pathogen suppression potential [200,201]. Protective effects of silicon [202,203], micronutrients [106,204] or inoculation with beneficial microorganisms (bioeffectors) [107] have proved their benefits for various agricultural crops, but the extent to which these can replace conventional CSPs is not clear.

In non-chemical weed control strategies such as in MECSs (Tables 2 and 3), multiple weed suppression strategies are required to secure crop yields. These include crop rotations with spring and winter seeding crops, including cover crops to reduce the density of problematic weed species such as blackgrass (Alopecurus myosuroides) [205]. Inversion tillage with a plow significantly reduces weed infestation compared to reduced tillage practices [206]. A false seedbed is also a suitable method to reduce weeds [207]. Curative weed control can be undertaken by harrowing, hoeing, and other physical methods that can be performed between and within rows. Hoes can uproot and cover larger weeds very effectively [156,208]. Manual steering of hoes between rows can be made more precise by automatic steering systems using GNSS (Global Navigation Satellite System) techniques and optical sensors. When automatically steered hoes are used, control success against weeds within rows is higher than with conventional hoes because automatically steered hoes can go faster $(10 \mathrm{~km} / \mathrm{h})$ and closer $( \pm 2 \mathrm{~cm})$. In addition, there is less damage to the crop.

Biological control agents (BCAs) can be an alternative to CSPs to control plant pests and diseases [167]. An indirect mode of action of BCAs is the induction of plant defense reactions. This will put plants in a so-called priming state. Priming describes a state in which the plant is prepared more quickly and more resiliently to deal with possible pathogen infection [209]. The detection and treatment of pathogen infections at an early stage is crucial for effective pathogen control. This requires innovative technologies for sensor-based pathogen monitoring and applying BCAs (Table 3), in addition to appropriate formulations and methods of application that attain successful establishment of BCAs in the field.

In addition to curative plant protection measures, without CSPs, the discussion about optimal soil management takes on new importance in the context of prophylactic plant protection. More intensive tillage (plough) can make a substantial contribution to yield stabilization by reducing the pressure of diseases, weeds, and pests, especially in MECSs. At the same time, however, negative effects on soil erosion in silt-dominated soil textures, and on soil organic matter content and nutrient cycles, can occur (Table 2). In this context, the effects of different soil management measures in conventional farming, organic farming, and MECSs must be investigated with respect to crop yield, product quality (e.g., F. graminearum infestations), and ecological indicators.

\subsubsection{Use of Precision Agriculture Technologies}

Many of the cultivation measures of MECSs will benefit from the use of precision farming technologies (Table 3). Innovative technologies such as autonomous vehicles, drone-based monitoring and application methods, and automated hoeing technology allow the optimization of seeding and fertilization, in addition to the early detection and treatment of plant pathogens, pests, and weeds, making MECSs effective and efficient.

Automated, camera-controlled methods of hoeing technology offer advantages, especially for specific sowing patterns such as equidistant seeding. More precise crop row detection can be undertaken using image analysis technology. Hoeing blades can be adjusted hydraulically/electronically and, in agricultural crops, weeds can be effectively suppressed with such hoeing technology. Camera-based methods offer the possibility of precisely detecting plant rows and also individual plants, and of using the information to steer machines and equipment $[174,175]$. With a camera-assisted inter-row hoe with automatic side shifting, the effectiveness of weed control between and within rows in soybean and maize can be increased to $85 \%$, compared to $70 \%$ for machine hoeing with manual guidance [210]. Even at a row spacing of 12.5-15 cm, certain camera-guided hoes can be used in cereals [174]. 
Many specific requirements of MECSs in terms of spatial distribution for seed placement, fertilizer application, and mechanical weed control can be met with the help of GNSS-controlled sensors, actuators, and autonomous vehicles that facilitate precise georeferenced seed and fertilizer distribution, and hoe steering. In recent years, it has been shown that soil fertilization with fertilizer depots in the soil, applied at specific rates, depths, and distances from the plant, can increase nutrient efficiency [211]. This is even more important given the increasingly dry periods. Therefore, fertilizers applied on the surface are increasingly at a disadvantage because precipitation is needed to make the nutrients available to the plants. Automated, highly uniform distribution of the plants and selective fertilizer applications into the soil are effective in increasing crop production, resource efficiency, and weed suppression. Existing autonomous platforms with the appropriate sensors and actuators can deliver a high level of automation.

For successful control of plant pathogens in MECSs using BCAs, an optimized application in terms of time and space is necessary. One potential technology for early detection of plant pathogens is the use of drone-based sensors that generate georeferenced image data. By combining hyperspectral cameras with modern data analysis methods, and comparing pathogen detection via sensor technology and molecular and conventional methods, it is possible to generate procedures for an early detection of plant pathogens and identify their location within the plant canopy for BCA application in the field (Table 3). The capabilities of sensor-based pathogen detection and quantification under controlled conditions have previously been demonstrated in several studies [212-214]. Multiple detection methods are currently being developed to establish a monitoring system for the detection of plant pathogens, which are expected to occur more frequently when CSPs are abandoned. Molecular methods enable the detection of pathogens within the plant, but also on crop residues or in the soil. They enable a holistic assessment of pathogen pressure in MECSs.

\subsubsection{Impact on Natural Regulatory Processes}

Soil organisms play an important role in the maintenance of different soil functions, i.e., subsequent supply of plant-available nutrients [215], detoxification/mineralization of organic pollutants [142], and stabilization of the soil structure [216]. Symbiotic interactions between soil microorganisms and various crops (e.g., mycorrhizae) protect crops from pathogenic fungi and enhance stress tolerance relating to drought [217]. However, soil microorganisms are influenced to a marked degree by crop management $[218,219]$. Pesticides usually evoke at least a short-term negative response in soil microorganisms and many soil animals, e.g., earthworms [220]. Accordingly, earthworms and beneficial species are expected to profit from the absence of CSPs. However, it is unclear to which extent this positive effect is relativized by the eventual need for more intensive soil tillage. Equidistant plant spacing is expected to lead to a homogeneous distribution not only of crop roots, but also of resources for soil organisms, and thus to improved efficiency of microbial transformation processes compared to conventional plant spacing.

Reducing the spread of plant pathogens plays a critical role in pathogen management. In conventional cropping systems, monogenic resistances in crop varieties and single mode of action pesticides exert strong selection pressure on pathogen populations, usually prompting the rapid development of resistances [221]. Sustainable management of pathogen populations includes the deceleration of pathogen evolution by (i) diversifying cropping practices (e.g., more complex crop rotations and small-scale cultivation); (ii) the use of multiple resistances on a polygenic basis in breeding; (iii) the cultivation of mixed varieties or mixed cultivation of different crops; and (iv) the development of new pest control methods such as BCAs (Table 2). This can result in the less frequent occurrence and slower spread of new resistance mutations in pathogen populations. In MECSs, the short-term application of CSPs in acute situations is not possible. Therefore, cultivation methods and plant breeding are of particular importance in MECSs. Intensive pathogen monitoring offers the possibility of predicting the epidemiology of pathogens. DNA sequencing, digital technologies, and machine learning techniques enable high temporal 
and spatial resolution monitoring of pathogen populations. This provides an important basis for designing cropping systems and setting breeding goals [222,223]. In particular, it needs to be investigated whether MECSs have a sustainable and positive effect on the spread of resistant and aggressive fungal pathogens, or if the exclusion of CSPs increases pathogen diversity, resulting in negative effects such as a faster evolutionary adaptation of pathogen populations.

The contribution of MECSs to increase biodiversity and strengthen natural pest control takes on a central role in the research and configuration of this new cropping system. Bengtsson et al. [54] and Tuck et al. [56] observed an increase of, on average, 30\% in species diversity in organic cropping systems compared to conventional cropping systems. In this context, the influence of farm management varies by type and scale, and loses significance as landscape diversity increases. Burel et al. [67] state that a minimum amount of seminatural land is required for biodiversity to be impacted at all by the type of management because many species cannot become established without sufficient habitats or seed stocks. When there are high proportions of semi-natural elements of about $20 \%$, biodiversity is highly independent of the type of management [160]. In contrast, the management form (varied crop rotation, reduced input of nutrients and chemical pesticides, minimum soil tillage, etc.) can significantly enhance biodiversity in regions with a proportion of seminatural areas of between 5 and $20 \%$, which applies to a large proportion of arable land. This suggests the need for a cross-scale and cross-process approach to representing landscape system processes. Individual parts of this system can be studied very well and precisely with analytical and empirical methods. However, due to the many scale transitions and the complexity of the system, observations of the entire system are almost only possible with models [224].

Overall, biodiversity is of prominent importance in the promotion of numerous ecosystem services with complementary and synergistic effects $[95,96]$. This is particularly the case for yield formation [22], pollination services [225], and natural pest regulation [226]. Against this backdrop, spatial heterogeneity is a key factor for biodiversity [22,227]. MECSs are expected to have positive effects on biodiversity across spatial scales, and to be reinforced by an optimal design of landscape structure, thereby enhancing natural pest regulation and crop yields from local to regional scales. The extent to which stable predatorprey relationships support natural pest regulation in arable farming must be investigated at a small scale. Predatory flies are particularly suited as a new indicator of functional biodiversity and for analyzing the effects of different cropping systems on predator-prey relationships. They have a small range of activity compared to other antagonists, and their populations are extremely susceptible to any disturbances. As a study model, predatory flies of the genus Platypalpus may be suitable, because they are important natural antagonists of crop-damaging flies and midges [228-230]. Because the larvae of predatory flies develop in the soil [229], active soil life is conducive to the abundance and diversity of species of these natural antagonists. Furthermore, the direct and indirect application of CSPs (e.g., limitation of prey or habitat changes) affects the abundance and effectiveness of these beneficial insects. Moreover, additional effects on predator prey relationships generated by crop management, such as crop rotation, spatial distribution of crop plants, and fertilization, need to be evaluated. At the landscape scale, the occurrence and spatial distribution of pests and antagonists depend on (i) field size, (ii) landscape structure, and (iii) temporal land-use dynamics. These effects on dynamic interaction networks need to be considered, to allow major benefits of natural pest control in large-scale MECSs to be predicted. In this context, synergistic interactions between MECSs and other biodiversityenhancing agri-environmental schemes, in particular the establishment of perennial flower strips, need to be quantified. 


\subsection{Mineral-Ecological Cropping Systems from the Perspective of Yield and Product Quality}

Refraining from the use of CSPs can severely affect crop yield and product quality, depending on disease and pest infestation or weed pressure. In MECSs, efforts must be made to keep these effects as low as possible through optimal design of the cropping system. The potential crop yield losses due to pests and pathogens in wheat production systems are estimated to be as high as $70 \%[41,99,101]$. However, due to conventional crop protection, the actual losses in agricultural practice amount to less than $20 \%$ [98]. In MECSs, refraining from the use of CSPs is expected to reduce yield levels and, above all, to increase spatial and temporal yield variability. In particular, pests and pathogens occurring epidemically and featuring a high yield loss potential are relevant in this context [88]. Yield losses lead not only to economic problems, but also to lower N-uptake, and thus reduced nutrient use efficiency and increased leaching risk. Therefore, the extent to which yields in MECSs can be stabilized by adjustments to the cropping system (equidistant seeding, crop variety selection, fertilizer management, etc.) needs to be investigated. The use of simulation models may serve to supplement the limited data on crop yield losses caused by pests and pathogens, to scale them up, and to evaluate scenarios on future or changed climatic, production, and cropping system conditions [231]. Process-based crop models, such as DSSAT-CROPSIM, simulate the soil-plant-atmosphere system, including abiotic stress due to water and nutrient deficiency. For a robust simulation of biotic stress, a sufficient empirical experimental database is essential for the calibration and validation of the crop model, and for the parameterization of specific pests, such as mites and nematodes, and their yield effects [232]. The validated model can be used to simulate the effects of not using CSPs in virtual experiments on yield, N-uptake, nitrogen use efficiency, and $\mathrm{N}$-leaching risk. Inter alia, the impact of cultivar choice can be simulated in the model by considering differences in phenology and resistance to specific pests.

In cropping systems without the use of CSPs, it can be expected that plants will be exposed to increased stress due to intensified weed and pathogen infestation if no other adaptation measures are implemented. In both cases, imbalances in the supply of nutrients, photosynthates, and water for plant metabolism can occur. These, in turn, affect the quality of the harvested products [124]. This mainly concerns products whose quality depends on the composition of primary metabolites (proteins, organic acids, sugars), because their distribution is significantly affected by source/sink ratios in the plant, and rapidly change under stress [233]. In cereals, for example, the composition and temporal development of the storage proteins, which are essential for the baking quality of flour, are markedly affected by the nutrient and water supply [127]. Although the external (sensoric) quality is demanded by consumers, and the internal quality by the processing industry, there are health aspects that give grounds for concern, e.g., increased fungal infestation (mycotoxins) of the harvested material. Compared to conventional cropping systems, individual quality parameters (especially protein composition) of harvest products are expected to change in MECSs as a result of the increased stress level. Furthermore, it is expected that, in the case of cereals, the temporal course of storage protein incorporation between the flowering and grain-filling phases will change, and thus also affect the "final quality" of the grains. The successful establishment and acceptance of mineral-ecological cultivation systems is only possible if these systems deliver products of sufficient quality in the long term, which also meet the technical requirements for product processing. It is expected that optimized fertilization will lead to a stabilization of plant metabolism, and thus to improved resilience against biotic and abiotic stressors. Equidistant plant spacing should result in improved nutrient and water appropriation capacity, and, in particular, stable product quality under drought stress. Whether the increased stress in MECSs can be countered by resistant crop varieties, optimized fertilization, and equidistant seeding, resulting in sufficient product qualities, has to be investigated. 


\subsection{Mineral-Ecological Cropping Systems from a Socio-Economic Perspective}

Economic efficiency and acceptance by farmers and consumers are major success factors for the establishment of MECSs. In terms of economics, MECSs will differ from both conventional and organic cropping systems [94,234]: Organic cropping systems are characterized by higher unit costs compared to conventional ones and, depending on the organic price premium, by higher reliance on government support. Against this background, analyses of unit costs and achievable market prices for products from MECSs including risk-related aspects and the preferences of stakeholders along the value-chain need careful consideration.

\subsubsection{Economic Aspects at Farm Level}

In MECSs, it is expected that not only the contribution margins, but also the contribution margin variances change as a result of higher yield fluctuations compared to conventional cropping systems. Hence, it is likely that rational farmers will try to adjust their production program in such a manner as to maximize the total contribution margin while maintaining a certain overall risk. This will depend on the risk tolerance of the individual actor. Linear programming models are common activity-analytical operating models in which the optimal production program of farms can be determined in each case by maximizing the total contribution margin subject to constraints [235]. These models are common activity-analytical operating models, but they do not take the total risk into account. To identify optimal risk-efficient cropping systems, the expected-value-variance criterion can be applied within the framework of quadratic risk programming [236,237]. For this purpose, farm models must be developed that allow the selection of cropping practices while maintaining acceptable economic risks (measured as the estimated total variance of the optimized operating profit). Stochastic risk analysis can be used to generate realistic variances.

\subsubsection{Economic Aspects at Regional Level}

It is not only in conventional cropping systems that the large-scale use of identical plant varieties and pesticide active ingredients is leading to increasing resistance of pathogens. In organic farming and MECSs, too, resistance to pathogens can be expected to diminish with large-scale use. If large-scale cultivation of identical varieties increases, the likelihood of progressively volatile crop yields due to pest and pathogen impacts will rise [238]. Already, the rapid development of pest and pathogen resistance to pesticide-active ingredients and the rapid loss of varietal resistance are playing an increasingly important role in arable agriculture, nationally and globally. Thus, resistance management is expected to gain further importance in the future [239]. It is expected that active ingredient efficiencies and varietal resistance will take on even more of a common property character, and that resistance and yield management will be improved by means of coordinated collective action by farmers based on individually negotiated solutions. In line with the "new institutional economics" [240], a concept for targeted collective action with respect to the preservation of crop variety resistance and stability of crop yields is being developed. In this concept, farmers will optimize the preservation of crop variety efficacy against pests and pathogens, and crop yield stability, by spatially and temporally coordinating suitable cropping and cultivation measures, in addition to suitable crop variety selection. This approach is based on the theory of self-organized and self-managed forms of collective action [241]. Voluntary agreements by farmers concerning a spatially defined unit are key factors. Despite the fact that information about ecosystem services other than yield and quality of the crops is still mostly unclear, they aim to achieve a Pareto optimal result as an incentive to conclude a negotiation. This is because the long-term surplus profit due to reduced costs and increased crop yields achieved through collective negotiation solutions can be high. Such cooperative approaches to achieving positive operational and environmental effects are also pursued by the EU in the context of recent EU CAP reform proposals [242]. 


\subsubsection{Perspective of the Agricultural Sector}

A new MECS brings with it many uncertainties for farmers. Numerous factors will decide whether this new cropping system will be adopted and implemented by agricultural operations. It is assumed that a new agricultural production regime without any CSPs can only be implemented on a wide scale if the guiding attitudes, social norms, and restrictions are recognized by practitioners in agricultural operations and specifically considered in corresponding strategies, for instance, related to advisory services or financial support schemes. In the agricultural sector, innovations have been debated almost entirely as the responsibility of the individual farms. However, the goal of dispensing with chemical pesticides is to a large extent being pushed on agriculture from within society. This raises the question of whether and how alliances between stakeholders in society and agricultural operations can promote the roll-out of agriculture based on a MECS as a concerted approach for a (particular) region. It is of decisive importance whether it will be possible to develop strategies that can be implemented on a partnership basis by various social actors (e.g., when agricultural operations receive appropriate support from local consumers). Key factors influencing acceptance and implementation of a MECS require deeper insights into the patterns of impact and leverages of promoting acceptance and implementation.

\subsubsection{Perspective of Society and the Food Chain}

The debate between the agricultural sector and civil society organizations regarding the future of agricultural systems (e.g., animal welfare) is highly polarized. MECSs will only be successful if they are not only accepted by farmers, but also trusted by key stakeholders and the food chain, and succeed in generating a willingness to pay among consumers. The existence of substantial barriers is highlighted by the example of "integrated cultivation", which (except for some minor exceptions in Switzerland) has failed to become established as a market segment among consumers [243]. Therefore, both consumer willingness to pay and acceptance by food producers and food retailers in the food chain must be determined in order to analyze the market barriers to the introduction of mineral-organic products. With respect to an introduction of barriers from a society perspective, the attitudes towards and trust in the new MECS among central stakeholders must be considered. According to the current state of research, consumer knowledge about CSPs is low and primarily based on mass media reporting. According to a study by the German Federal Institute for Risk Assessment (BfR), a skeptical attitude dominates: 67\% of citizens consider CSPs to be harmful to humans even under normal conditions of use; three quarters consider CSPs to be unnecessary for food production. Furthermore, the majority of respondents suspect that there are regulatory deficits in application monitoring and pesticide residue controls [244,245]. Several studies show that consumers' pesticide-related concerns are associated with a greater preference for organic food [246-248]. The omitted use of CSPs or the absence of pesticide residues is a significant characteristic of organic food from a consumer's point of view [249-251]. Hence, positive effects to cater for the needs of many consumers for pesticide-free food have been derived particularly for organic agriculture and the sales of organic food [252]. To date, in Germany no studies have been conducted on consumer willingness to pay for or buy foods from agricultural systems that are specifically characterized by the absence of CSPs. Previous studies in various countries show that the highest proportion of consumers surveyed has a majority willingness (MW) to pay up to $10 \%$ more for pesticide-free foods than for conventional products. This finding is evident in studies from Canada (67.1\% of consumer MW of 1-10\%, [253]), the United States (66.1\% of consumer MW of $5-10 \%$, Ott, $1990 ; 30 \%$ of consumer MW of up to $10 \%$, [254]), and Italy (34\% of consumer MW of $6-10 \%$, [255]). Although some of these studies are over twenty years old, they indicate that consumers show a positive willingness to pay for products from MECSs. Numerous studies on organic food show that expectations of organic products go beyond the foregoing of CSPs. This means that products from MECSs could possibly occupy a mid-market position. However, it is assumed that foods from MECSs can be clearly classified, valued, and accordingly positioned on the market by 
consumers as a consequence of the consistent exclusion of CSPs. Against this backdrop, the assumption would also seem to be that consumers view the absence of chemical pesticides as an important indicator of the naturalness of foods and that naturalness is of major or growing relevance as a criterion when shopping for food [256]. It remains to be seen whether consumers are less willing to pay for products from MECSs than for organic food. This attitude would, nonetheless, suffice to secure a successful positioning in the mid-market segment given the significantly lower additional costs of the cropping system. It is postulated for the food chain that the food retail trade will prefer products without any CSPs for risk and reputation reasons. Studies on the classification and estimation of social discourse are particularly complex, because they are driven not only by interests, but also by strategic positions, tactical calculations, and opportunities [257,258].

\subsection{Mineral-Ecological Cropping Systems from the Perspective of Ecosystem Services}

As shown in Table 2, individual agricultural cultivation measures can have a variety of positive or negative effects on the different ecosystem services of agricultural landscapes. Due to the ecotoxicity potential of CSPs, their avoidance is expected to have a positive impact on biodiversity, species diversity, and abundance, both in agricultural landscapes and in agricultural soils [123,140,141,259]. In addition, positive ecological effects can be expected from the measures specifically investigated in MECSs, particularly from the fertilization strategies. The application of ammonium depots and nitrification inhibitors can reduce the amount of nitrogen fertilizer used, thereby decreasing both the risk of nitrate leaching, and greenhouse gas emissions from the field and from the upstream fertilizer production [131]. Promoting biodiversity and natural ecosystem processes also enhances many aspects of cultural services (see Table 2) [171,260-262]. However, refraining from CSPs can also lead to a deterioration in crop supply services and environmental disadvantages if yield losses cannot be compensated by crop management measures as described above in Section 4.2 A significant decrease in crop yield because of the system conversion would have a negative impact on the environmental efficiency of crop production, because the environmental burdens would be attributed to lower output [130,261-265]. As a result, the total environmental burdens, for instance in the categories of eutrophication, acidification, and climate change, would be expected to increase [130]. Lower crop yields would also have further indirect effects, such as additional demand for agricultural land [266,267]. Globally, the expansion of agricultural land, along with other areas used by man (settlement areas, etc.) is one of the strongest drivers of biodiversity loss [268]. When switching from conventional cropping systems to MECSs, a variety of trade-offs within ecological services, and between production, quality, and ecological targets, are to be expected. Given the complex nature of causal relationships, the effects of individual cultivation measures on ecosystem services cannot be assessed separately, but must be evaluated as a package of measures of a cropping system [182,269]. Life cycle assessment (LCA) is an effective tool for the comparative assessment of cropping systems [270,271]. Firstly, it can be used to allocate the various emissions generated along the value chain of MECSs, for instance in the production of operating resources and land use, to specific environmental impacts. In this manner, the diverse environmental impacts of mineral-ecological, conventional, and organic cropping systems can be quantified and compared. Secondly, "hot spots" within the cropping systems can be identified, which provide indications of particularly effective approaches for optimization of the supply of ecosystem services [266]. Therefore, ecological analyses can help identify combinations of agroecological practices and modern production techniques that maintain the productivity while reducing emissions. This can help avoid negative environmental impacts, ideally without any loss of crop yield or product quality, and then develop strategies to balance trade-offs between economic and ecological goals in MECSs [272].

However, the quantification of some ecosystem services is beyond the traditional scope of LCAs, particularly those of soil quality and biodiversity [273,274]. A comprehensive evaluation of MECSs in comparison to conventional and organic cropping systems 
must consider the latest developments in methodology. For the measurement of soil quality, the LANCA method provides appropriate characterization factors for five soil-specific impact categories [275]. "Countryside species-area relationships" can be used to measure biodiversity in LCAs [276]. To demonstrate the advantages and disadvantages of modern agricultural technologies and agricultural measures on biodiversity, it is necessary to extend the scope of the assessment and further investigate the relationship between biodiversity and ecosystem services [277]. Therefore, the assessment methods of ecosystem services must be further developed for a comprehensive evaluation of MECSs through the collaboration of life cycle assessors, and particularly that of economists, ecologists, and soil scientists.

\section{Conclusions}

Through continuous further development and optimization of cropping systems, agriculture must continue to secure future global food supplies while, at the same time, preserving natural livelihoods. In addition to conventional and organic systems, advanced cropping systems are needed to improve the ecosystem services of agricultural landscapes. Depending on local and global requirements, different cropping systems may be beneficial. The individual ecosystem services (provisioning, regulating, habitat, and cultural services) must be balanced in the local and global context. The development of mineral-ecological cropping systems follows a new farming concept that aims at minimizing trade-offs between different ecosystem services and promoting synergies. This applies not only to the agricultural area under consideration, but also to interactions with areas and structures outside the agricultural landscape, especially with regard to pollutant inputs and land use changes, as well as to natural regulation processes. Future analyses of these new cropping systems should focus on investigating the extent to which it is possible to improve the ecosystem services of agricultural landscapes by establishing mineral-ecological cropping systems with optimized mineral fertilization, yet without the use of chemical synthetic plant protection products.

Author Contributions: Conceptualization, B.Z., I.C.-M., E.B., I.L., M.v.C.; methodology, B.Z., I.C.-M., M.v.C., E.B., I.L.; data curation, B.Z., I.C.-M., M.v.C., I.L., J.W., A.S. (Achim Spiller), S.N., C.L., T.K., I.P., C.Z., M.A.W., M.D., F.M.S., J.P., A.R., H.K., T.F., B.K., R.L., S.K., S.K.-H., J.G., A.E.-H., S.T., M.R., K.S., T.S., J.I., U.L., G.N., N.M., T.M., K.B., M.G., E.K., S.M. (Sven Marhan), R.S., H.-W.G., D.R., A.S. (Alexander Stana), S.G.-H., S.M. (Sebastian Munz), D.O., R.G., M.S., W.H., J.S., M.F., M.K., H.-P.P., P.R., K.W., S.Z., G.P., N.S., R.T.V., E.B.; writing—original draft preparation, B.Z., I.C.-M., E.B., I.L., M.v.C.; writing-review and editing, B.Z., I.C.-M., M.v.C., I.L., J.W., A.S. (Achim Spiller), S.N., C.L., T.K., I.P., C.Z., M.A.W., M.D., F.M.S., J.P., A.R., H.K., T.F., B.K., R.L., S.K., S.K.-H., J.G., A.E.-H., S.T., M.R., K.S., T.S., J.I., U.L., G.N., N.M., T.M., K.B., M.G., E.K., S.M. (Sven Marhan), R.S., H.-W.G., D.R., A.S. (Alexander Stana), S.G.-H., S.M. (Sebastian Munz), D.O., R.G., M.S., W.H., J.S., M.F., M.K., H.-P.P., P.R., K.W., S.Z., G.P., N.S., R.T.V., E.B.; visualization, B.Z., I.C.-M., M.v.C., E.B., I.L.; supervision, E.B., R.T.V., I.L., A.S. (Achim Spiller), C.L., C.Z., F.M.S., H.K., T.F., S.K., K.S., T.S., U.L., G.N., T.M., E.K., H.-W.G., S.G.-H., R.G., W.H., J.S.; project administration, E.B., R.T.V., N.S., I.C.-M., B.Z.; funding acquisition, E.B., H.K., A.S. (Achim Spiller). All authors have read and agreed to the published version of the manuscript.

Funding: This research was funded by Bundesministerium für Bildung und Forschung (BMBF), grant number 031B0731A. The APC was funded by Bundesministerium für Bildung und Forschung (BMBF), grant number 031B0731A.

Data Availability Statement: Data sharing is not applicable to this article.

Conflicts of Interest: The authors declare no conflict of interest. The funders had no role in the design of the study; in the collection, analyses, or interpretation of data; in the writing of the manuscript, or in the decision to publish the results. 


\section{References}

1. Godfray, H.C.J.; Beddington, J.R.; Crute, I.R.; Haddad, L.; Lawrence, D.; Muir, J.F.; Pretty, J.; Robinson, S.; Thomas, S.M.; Toulmin, C. Food Security: The Challenge of Feeding 9 Billion People. Science 2010, 327, 812-818. [CrossRef] [PubMed]

2. FAO. Transforming Food and Agriculture to Achieve the SDGs-20 Interconnected Actions to Guide Decision-Makers; Food and Agriculture Organization of the United Nations: Rome, Italy, 2018; ISBN 978-92-5-130626-0.

3. IPBES. Summary for Policymakers of the Global Assessment Report on Biodiversity and Ecosystem Services of the Intergovernmental Science-Policy Platform on Biodiversity and Ecosystem Services; Díaz, S., Settele, J., Brondízio, E., Ngo, H., Guèze, M., Agard, J., Arneth, A., Balvanera, P., Brauman, K., Butchart, S., Eds.; IPBES Secretariat: Bonn, Germany, 2019; ISBN 978-3-947851-13-3.

4. Rockström, J.; Steffen, W.; Noone, K.; Persson, Å.; Chapin, F.S., III; Lambin, E.F.; Lenton, T.M.; Scheffer, M.; Folke, C.; Shellnhuber H.J.; et al. A Safe Operating Space for Humanity. Nature 2009, 461, 472-475. [CrossRef] [PubMed]

5. Zabel, F.; Delzeit, R.; Schneider, J.M.; Seppelt, R.; Mauser, W.; Václavík, T. Global Impacts of Future Cropland Expansion and Intensification on Agricultural Markets and Biodiversity. Nat. Commun. 2019, 10, 2844. [CrossRef] [PubMed]

6. Kopittke, P.M.; Menzies, N.W.; Wang, P.; McKenna, B.A.; Lombi, E. Soil and the Intensification of Agriculture for Global Food Security. Environ. Int. 2019, 132, 105078. [CrossRef] [PubMed]

7. Benton, T.G.; Bieg, C.; Harwatt, H.; Pudasaini, R.; Wellesley, L. Food System Impacts on Biodiversity Loss Three Levers for Food System Transformation in Support of Nature; Chatham House: London, UK, 2021.

8. Barthel, S.; Isendahl, C.; Vis, B.N.; Drescher, A.; Evans, D.L.; van Timmeren, A. Global Urbanization and Food Production in Direct Competition for Land: Leverage Places to Mitigate Impacts on SDG2 and on the Earth System. Anthr. Rev. 2019, 6, 71-97. [CrossRef]

9. Gardi, C.; Panagos, P.; Liedekerke, M.V.; Bosco, C.; Brogniez, D.D. Land Take and Food Security: Assessment of Land Take on the Agricultural Production in Europe. J. Environ. Plan. Manag. 2015, 58, 898-912. [CrossRef]

10. Lambin, E.F.; Meyfroidt, P. Global Land Use Change, Economic Globalization, and the Looming Land Scarcity. Proc. Natl. Acad. Sci. USA 2011, 108, 3465-3472. [CrossRef]

11. Tilman, D.; Balzer, C.; Hill, J.; Befort, B.L. Global Food Demand and the Sustainable Intensification of Agriculture. Proc. Natl. Acad. Sci. USA 2011, 108, 20260-20264. [CrossRef]

12. Lambin, E.F.; Meyfroidt, P. Trends in Global Land-Use Competition; The MIT Press: Cambridge, MA, USA, 2014; ISBN 978-0-262-32212-6.

13. Foley, J.A.; Ramankutty, N.; Brauman, K.A.; Cassidy, E.S.; Gerber, J.S.; Johnston, M.; Mueller, N.D.; O'Connell, C.; Ray, D.K.; West, P.C.; et al. Solutions for a Cultivated Planet. Nature 2011, 478, 337-342. [CrossRef]

14. Haller, L.; Moakes, S.; Niggli, U.; Riedel, J.; Stolze, M.; Thompson, M. Entwicklungsperspektiven Der Ökologischen Landwirtschaft in Deutschland; Umweltbundesamt: Dessau-Roßlau, Germany, 2020.

15. Niggli, U.; Riedel, J. Entwicklungsperspektiven Für Die Ökologische Landwirtschaft in Deutschland-Vorstellung Der Szenarien In Proceedings of the UBA-Workshop zum Sachverständigengutachten, Berlin, Germany, 22-23 September 2020.

16. NOcsPS. LaNdwirtschaft 4.0 Ohne Chemisch-Synthetischen PflanzenSchutz. 2021. Available online: https://nocsps.unihohenheim.de (accessed on 6 March 2021).

17. De Groot, R.; Brander, L.; Van Der Ploeg, S.; Costanza, R.; Bernard, F.; Braat, L.; Christie, M.; Crossman, N.; Ghermandi, A.; Hein, L. Global Estimates of the Value of Ecosystems and Their Services in Monetary Units. Ecosyst. Serv. 2012, 1, 50-61. [CrossRef]

18. De Groot, R.; Brander, L.; Solomonides, S. Update of Global Ecosystem Service Valuation Database (ESVD); Wageningen University \& Research: Wageningen, The Netherlands, 2020.

19. Costanza, R.; d'Arge, R.; De Groot, R.; Farber, S.; Grasso, M.; Hannon, B.; Limburg, K.; Naeem, S.; O'neill, R.V.; Paruelo, J. The Value of the World's Ecosystem Services and Natural Capital. Nature 1997, 387, 253. [CrossRef]

20. Vogt, G. Geschichte des Ökologischen Landbaus Im Deutschsprachigen Raum. Ökologie Landbau 2001, 118, 47-49.

21. Lauk, C. Sozial-Ökologische Charakteristika von Agrarsystemen. Ein Globaler Überblick Und Vergleich. In Social Ecology Working Paper; Institute of Social Ecology: Vienna, Austria, 2005.

22. Batáry, P.; Gallé, R.; Riesch, F.; Fischer, C.; Dormann, C.F.; Mußhoff, O.; Császár, P.; Fusaro, S.; Gayer, C.; Happe, A.-K.; et al. The Former Iron Curtain Still Drives Biodiversity-Profit Trade-Offs in German Agriculture. Nat. Ecol. Evol. 2017, 1, 1279-1284. [CrossRef]

23. Kremen, C.; Merenlender, A.M. Landscapes That Work for Biodiversity and People. Science 2018, 362. [CrossRef]

24. Pretty, J.; Benton, T.G.; Bharucha, Z.P.; Dicks, L.V.; Flora, C.B.; Godfray, H.C.J.; Goulson, D.; Hartley, S.; Lampkin, N.; Morris, C.; et al. Global Assessment of Agricultural System Redesign for Sustainable Intensification. Nat. Sustain. 2018, 1, 441-446. [CrossRef]

25. Renwick, A.; Schellhorn, N. A perspective on land sparing versus land sharing. In Learning from Agri-Environment Schemes in Australia; Ansell, D., Gibson, F., Salt, D., Eds.; Australian National University Press: Acton, ACT, Australia, 2016 ; pp. 117-125. ISBN 978-1-76046-015-0.

26. Altieri, M.A.; Nicholls, C.I.; Montalba, R. Technological Approaches to Sustainable Agriculture at a Crossroads: An Agroecological Perspective. Sustainability 2017, 9, 349. [CrossRef]

27. Arbenz, M.; Gould, D.; Stopes, C. ORGANIC 3.0-The Vision of the Global Organic Movement and the Need for Scientific Support. Org. Agr. 2017, 7, 199-207. [CrossRef]

28. Adams, D.C.; Salois, M.J. Local versus Organic: A Turn in Consumer Preferences and Willingness-to-Pay. Renew. Agric. Food Syst. 2010, 25, 331-341. [CrossRef] 
29. Kratochvil, R. Biologischer Landbau Und Nachhaltige Entwicklung: Kongruenzen, Differenzen Und Herausforderungen. Bio-Landbau Österreich Im Int. Kontext 2005, 2, 85-104.

30. IFOAM Definition of Organic Agriculture. 2021. Available online: http://www.ifoam.bio/en/organic-landmarks/definitionorganic-agriculture (accessed on 6 February 2021).

31. Wezel, A.; Herren, B.G.; Kerr, R.B.; Barrios, E.; Gonçalves, A.L.R.; Sinclair, F. Agroecological Principles and Elements and Their Implications for Transitioning to Sustainable Food Systems. A Review. Agron. Sustain. Dev. 2020, 40, 40. [CrossRef]

32. Willer, H.; Schlatter, B.; Trávníček, J.; Kemper, L.; Lernoud, J. The World of Organic Agriculture. Statistics and Emerging Trends 2020, 1st ed.; FiBL: Frick, Switzerland; IFOAM: Bonn, Germany, 2020.

33. FAO; WHO. The International Code of Conduct on Pesticide Management; FAO: Rome, Italy; WHO: Geneva, Switzerland, 2014.

34. EISA. European Integrated Farming Framework. A European Definition and Characterisation of Integrated Farming (IF) as Guideline for Sustainable Development of Agriculture; European Initiative for Sustainable Development in Agriculture: Erkelenz, Germany, 2012; Available online: http:/ / www.sustainable-agriculture.org/wp-content/uploads/2012/08/EISA_Framework_english_new_ wheel_170212.pdf (accessed on 25 August 2021).

35. EU Verordnung. (EG) Nr. 834/2007 Des Rates Vom 28. Juni 2007 Über Die Ökologische/Biologische Produktion Und Die Kennzeichnung von Ökologischen/Biologischen Erzeugnissen Und Zur Aufhebung Der Verordnung (EWG) Nr. 2092/91; European Commission: Brussels: Bruxelles, Belgium, 2007.

36. Demeter Richtlinien. Erzeugung Und Verarbeitung. Richtlinien Für Die Zertifizierung "Demeter" Und "Biodynamisch"; Demeter: Darmstadt, Germany, 2021.

37. IFOAM IFOAM. Organics International. 2021. Available online: https:/ / www.ifoam.bio/ (accessed on 21 June 2021).

38. IFOAM IFOAM. Organics Europe. 2021. Available online: https://www.organicseurope.bio/ (accessed on 21 June 2021).

39. FAO. Climate-Smart Agriculture; FAO: Rome, Italy, 2021.

40. Newton, P.; Civita, N.; Frankel-Goldwater, L.; Bartel, K.; Johns, C. What Is Regenerative Agriculture? A Review of Scholar and Practitioner Definitions Based on Processes and Outcomes. Front. Sustain. Food Syst. 2020, 4, 194. [CrossRef]

41. EPRS. Präzisionslandwirtschaft Und DieZukunft Der Landwirtschaft in Europa; European Parliament: Brussels, Belgium, 2016.

42. Pretty, J.; Bharucha, P. Current Approaches to Sustainable Food and Agriculture. In Sustainable Food and Agriculture; Campanhola, C., Pandey, S., Eds.; Academic Press: Cambridge, MA, USA, 2019; pp. 169-170. ISBN 978-0-12-812134-4.

43. Pretty, J.; Bharucha, Z.P. Sustainable Intensification in Agricultural Systems. Ann. Bot. 2014, 114, 1571-1596. [CrossRef]

44. Wezel, A.; Soboksa, G.; McClelland, S.; Delespesse, F.; Boissau, A. The Blurred Boundaries of Ecological, Sustainable, and Agroecological Intensification: A Review. Agron. Sustain. Dev. 2015, 35, 1283-1295. [CrossRef]

45. Mockshell, J.; Kamanda, J. Beyond the Agroecological and Sustainable Agricultural Intensification Debate: Is Blended Sustainability the Way Forward? Int. J. Agric. Sustain. 2018, 16, 127-149. [CrossRef]

46. Wezel, A.; Casagrande, M.; Celette, F.; Vian, J.-F.; Ferrer, A.; Peigné, J. Agroecological Practices for Sustainable Agriculture. A Review. Agron. Sustain. Dev. 2014, 34,1-20. [CrossRef]

47. Worldbank Climate-Smart Agriculture. Available online: https://www.worldbank.org/en/topic/climate-smart-agriculture (accessed on 27 January 2021).

48. CSA. How Is Climate-Smart Agriculture Different from Other Sustainable Agriculture Approaches? 2021. Available online: https: / /csa.guide/csa/how-is-it-different (accessed on 6 February 2021).

49. Campbell, B.M.; Thornton, P.; Zougmoré, R.; van Asten, P.; Lipper, L. Sustainable Intensification: What Is Its Role in Climate Smart Agriculture? Curr. Opin. Environ. Sustain. 2014, 8, 39-43. [CrossRef]

50. KraichgauKorn Marktgemeinschaft KraichgauKorn. 2021. Available online: https://kkhomepage.kraichgaukorn.de/ (accessed on 6 February 2021).

51. Blütenkorn Für Mensch und Natur Die Zukunft nachhaltiger Landwirtschaft. 2021. Available online: https:/ /bluetenkorn.de/ (accessed on 2 June 2021).

52. IP-Suisse IP-SUISSE Bauern Denken an Morgen. 2021. Available online: https://www.ipsuisse.ch/ (accessed on 6 March 2021).

53. Sanders, J.; Heß, J. Leistungen des Ökologischen Landbaus Für Umwelt Und Gesellschaft; Thünen Report; Johann Heinrich von Thünen-Institut: Braunschweig, Germany, 2019.

54. Bengtsson, J.; Ahnström, J.; Weibull, A.-C. The Effects of Organic Agriculture on Biodiversity and Abundance: A Meta-Analysis. J. Appl. Ecol. 2005, 42, 261-269. [CrossRef]

55. Hole, D.G.; Perkins, A.J.; Wilson, J.D.; Alexander, I.H.; Grice, P.V.; Evans, A.D. Does Organic Farming Benefit Biodiversity? Biol. Conserv. 2005, 122, 113-130. [CrossRef]

56. Tuck, S.L.; Winqvist, C.; Mota, F.; Ahnström, J.; Turnbull, L.A.; Bengtsson, J. Land-Use Intensity and the Effects of Organic Farming on Biodiversity: A Hierarchical Meta-Analysis. J. Appl. Ecol. 2014, 51, 746-755. [CrossRef] [PubMed]

57. Tuomisto, H.L.; Hodge, I.D.; Riordan, P.; Macdonald, D.W. Does Organic Farming Reduce Environmental Impacts?-A MetaAnalysis of European Research. J. Environ. Manage. 2012, 112, 309-320. [CrossRef]

58. Mondelaers, K.; Aertsens, J.; Van Huylenbroeck, G. A Meta-analysis of the Differences in Environmental Impacts between Organic and Conventional Farming. Br. Food J. 2009, 111, 1098-1119. [CrossRef]

59. Seufert, V.; Ramankutty, N. Many Shades of Gray-The Context-Dependent Performance of Organic Agriculture. Sci. Adv. 2017, 3, e1602638. [CrossRef] 
60. Riedel, J.; Niggli, U. Ökologische Und Soziale Vorzüglichkeit versus Globale Ökoeffizienz. In Proceedings of the UBA-Workshop zum Sachverständigengutachten, Berlin, Germany, 27 July 2020.

61. Ponisio, L.C.; M'Gonigle, L.K.; Mace, K.C.; Palomino, J.; de Valpine, P.; Kremen, C. Diversification Practices Reduce Organic to Conventional Yield Gap. Proc. R. Soc. B Biol. Sci. 2015, 282, 20141396. [CrossRef]

62. De Ponti, T.; Rijk, B.; van Ittersum, M.K. The Crop Yield Gap between Organic and Conventional Agriculture. Agric. Syst. 2012, 108, 1-9. [CrossRef]

63. Seufert, V.; Ramankutty, N.; Foley, J.A. Comparing the Yields of Organic and Conventional Agriculture. Nature 2012, 485, $229-232$. [CrossRef]

64. BMEL Buchführung Der Testbetriebe; Bundesministerium für Ernährung, Landwirtschaft und Verbraucherschutz: Berlin, Germany, 2019.

65. Treu, H.; Nordborg, M.; Cederberg, C.; Heuer, T.; Claupein, E.; Hoffmann, H.; Berndes, G. Carbon Footprints and Land Use of Conventional and Organic Diets in Germany. J. Clean. Prod. 2017, 161, 127-142. [CrossRef]

66. Bommarco, R.; Kleijn, D.; Potts, S.G. Ecological Intensification: Harnessing Ecosystem Services for Food Security. Trends Ecol. Evol. 2013, 28, 230-238. [CrossRef] [PubMed]

67. Burel, F.; Aviron, S.; Baudry, J.; Le Féon, V.; Vasseur, C. The Structure and Dynamics of Agricultural Landscapes as Drivers of Biodiversity. In Landscape Ecology for Sustainable Environment and Culture; Fu, B., Jones, K.B., Eds.; Springer: Dordrecht, The Netherlands, 2013; pp. 285-308. ISBN 978-94-007-6530-6.

68. Raudsepp-Hearne, C.; Peterson, G.D.; Bennett, E.M. Ecosystem Service Bundles for Analyzing Tradeoffs in Diverse Landscapes. Proc. Natl. Acad. Sci. USA 2010, 107, 5242-5247. [CrossRef]

69. Wolters, V.; Isselstein, J.; Stützel, H.; Ordon, F.; von Haaren, C.; Schlecht, E.; Wesseler, J.; Birner, R.; von Lützow, M.; Brüggemann, N. Nachhaltige Ressourceneffiziente Erhöhung Der Flächenproduktivität: Zukunftsoptionen Der Deutschen Agrarökosystemforschung Grundsatzpapier Der Dfg Senatskommission Für Agrarökosystemforschung. J. Für Kult. 2014, 7, $225-236$.

70. Reid, W.V.; Mooney, H.A.; Cropper, A.; Capistrano, D.; Carpenter, S.R.; Chopra, K.; Dasgupta, P.; Dietz, T.; Duraiappah, A.K.; Hassan, R.; et al. Ecosystems and Human Well-Being: General Synthesis; Sarukhán, J., Whyte, A., Eds.; Island Press: Washington, DC, USA, 2005.

71. Rodríguez, J.; Beard, J.; Bennett, E.; Cumming, G.; Cork, S.; Agard, J.; Dobson, A.; Peterson, G. Trade-Offs across Space, Time, and Ecosystem Services. Ecol. Soc. 2006, 11. [CrossRef]

72. Meemken, E.-M.; Qaim, M. Organic Agriculture, Food Security, and the Environment. Annu. Rev. Resour. Econ. 2018, 10, 39-63. [CrossRef]

73. European Commission. Factsheet: From Farm to Fork: Our Food, Our Health, Our Planet, Our Future; European Commission: Brussels, Belgium, 2020.

74. ERA European Research Alliance. Towards a Chemical Pesticide Free Agriculture; European Research Alliance: Paris, France, 2021.

75. European Commission Directive. 2009/128/EC of the European Parliament and of the Council of 21 October 2009 Establishing a Framework for Community Action to Achieve the Sustainable Use of Pesticides. Off. J. Eur. Union 2009, 52, 71-86.

76. Lamichhane, J.R.; Messéan, A.; Ricci, P. Chapter Two-Research and innovation priorities as defined by the Ecophyto plan to address current crop protection transformation challenges in France. In Advances in Agronomy; Sparks, D.L., Ed.; Academic Press: Cambridge, MA, USA, 2019; Volume 154, pp. 81-152.

77. Lapierre, M.; Sauquet, A.; Julie, S. Providing Technical Assistance to Peer Networks to Reduce Pesticide Use in Europe: Evidence from the French Ecophyto Plan. 2019. hal-02190979v1. Available online: https://hal.archives-ouvertes.fr/hal-02190979v1 (accessed on 25 August 2021).

78. Bundesrat Entwurf Eines Gesetzes Zur Durchführung Der Im Rahmen Der Gemeinsamen Agrarpolitik Finanzierten Direktzahlungen (GAP-Direktzahlungen-Gesetz-GAPDZG). 2021. Available online: https:/ / www.bundesrat.de/SharedDocs / beratungsvorgaenge/2021/0301-0400/0301-21.html (accessed on 25 August 2021).

79. Delbrück, K.; Nürnberg, M. Aktionsprogramm Insektenschutz Gemeinsam Wirksam Gegen Das Insektensterben; Bundesministerium für Umwelt, Naturschutz und nukleare Sicherheit (BMU): Berlin, Germany, 2019.

80. MLR Gesetzesnovelle Zur Stärkung Der Biodiversität. 2020. Available online: https://mlr.baden-wuerttemberg.de/de/unserethemen/biodiversitaet-und-landnutzung/biodiversitaetsgesetz/ (accessed on 31 May 2021).

81. European Commission. Regulation (EC) No 1107/2009 of the European Parliament and of the Council of 21 October 2009 Concerning the Placing of Plant Protection Products on the Market and Repealing Council Directives 79/117/EEC and 91/414/EEC. Off. J. Eur. Union 2009, 52, 1-50.

82. Voss-Fels, K.P.; Stahl, A.; Wittkop, B.; Lichthardt, C.; Nagler, S.; Rose, T.; Chen, T.-W.; Zetzsche, H.; Seddig, S.; Majid Baig, M.; et al. Breeding Improves Wheat Productivity under Contrasting Agrochemical Input Levels. Nat. Plants 2019, 5, 706-714. [CrossRef]

83. Strassemeyer, J.; Daehmlow, D.; Dominic, A.R.; Lorenz, S.; Golla, B. SYNOPS-WEB, an Online Tool for Environmental Risk Assessment to Evaluate Pesticide Strategies on Field Level. Crop. Prot. 2017, 97, 28-44. [CrossRef]

84. Tola, M.; Kebede, B. Occurrence, Importance and Control of Mycotoxins: A Review. Cogent Food Agric. 2016, 2, 1191103. [CrossRef]

85. Zain, M.E. Impact of Mycotoxins on Humans and Animals. J. Saudi Chem. Soc. 2011, 15, 129-144. [CrossRef]

86. Bryden, W.L. Mycotoxin Contamination of the Feed Supply Chain: Implications for Animal Productivity and Feed Security. Anim. Feed Sci. Technol. 2012, 173, 134-158. [CrossRef] 
87. Feike, T.; zu Eisenbach, L.R.F.; Lieb, R.; Gabriel, D.; Sabboura, D.; Shawon, A.R.; Wetzel, M.; Klocke, B.; Krengel-Horney, S.; Schwarz, J. Einfluss von Pflanzenschutzstrategie und Bodenbearbeitung auf den $\mathrm{CO}_{2}$-Fußabdruck von Weizen. JFK 2020, 72 , 311-326. [CrossRef]

88. Laidig, F.; Feike, T.; Hadasch, S.; Rentel, D.; Klocke, B.; Miedaner, T.; Piepho, H.P. Breeding Progress of Disease Resistance and Impact of Disease Severity under Natural Infections in Winter Wheat Variety Trials. Appl. Genet. 2021, 134, 1281-1302. [CrossRef]

89. Deike, S.; Pallutt, B.; Christen, O. Investigations on the Energy Efficiency of Organic and Integrated Farming with Specific Emphasis on Pesticide Use Intensity. Eur. J. Agron. 2008, 28, 461-470. [CrossRef]

90. Herwig, N.; Felgentreu, D.; Hommel, B. Auswirkungen von natürlichen Standortbedingungen und ackerbaulichen Maßnahmen auf Bodenorganismen-Erhebungen in den Langzeitversuchen des Julius Kühn-Instituts in Dahnsdorf (Hoher Fläming, Land Brandenburg). JFK 2020, 72, 327-337. [CrossRef]

91. Klocke, B.; Wagner, C.; Schwarz, J. Erkenntnisse und Perspektiven eines 23-jährigen Dauerfeldversuches zum integrierten Pflanzenschutz gegen pilzliche Schaderreger im Winterweizen. JFK 2020, 72, 265-278. [CrossRef]

92. Schwarz, J.; Klocke, B.; Wagner, C.; Krengel, S. Untersuchungen zum notwendigen Maß bei der Anwendung von Pflanzenschutzmitteln in Winterweizen in den Jahren 2004 bis 2016. Gesunde Pflanz Pflanzenschutz Verbrauch. Umweltschutz 2018, 70, 119-127. [CrossRef]

93. Jahn, M.; Wagner, C.; Sellmann, J. Ertragsverluste durch wichtige Pilzkrankheiten in Winterweizen im Zeitraum 2003 bis 2008-Versuchsergebnisse aus 12 deutschen Bundesländern. J. Für Kult. 2012, 64, 273-285.

94. Lechenet, M.; Deytieux, V.; Antichi, D.; Aubertot, J.-N.; Bàrberi, P.; Bertrand, M.; Cellier, V.; Charles, R.; Colnenne-David, C.; Dachbrodt-Saaydeh, S.; et al. Diversity of Methodologies to Experiment Integrated Pest Management in Arable Cropping Systems: Analysis and Reflections Based on a European Network. Eur. J. Agron. 2017, 83, 86-99. [CrossRef]

95. Garibaldi, L.A.; Andersson, G.K.S.; Requier, F.; Fijen, T.P.M.; Hipólito, J.; Kleijn, D.; Pérez-Méndez, N.; Rollin, O. Complementarity and Synergisms among Ecosystem Services Supporting Crop Yield. Glob. Food Secur. 2018, 17, 38-47. [CrossRef]

96. Dainese, M.; Martin, E.A.; Aizen, M.A.; Albrecht, M.; Bartomeus, I.; Bommarco, R.; Carvalheiro, L.G.; Chaplin-Kramer, R.; Gagic, V.; Garibaldi, L.A.; et al. A Global Synthesis Reveals Biodiversity-Mediated Benefits for Crop Production. Sci. Adv. 2019,5 , eaax0121. [CrossRef]

97. Tamburini, G.; Bommarco, R.; Wanger, T.C.; Kremen, C.; van der Heijden, M.G.A.; Liebman, M.; Hallin, S. Agricultural Diversification Promotes Multiple Ecosystem Services without Compromising Yield. Sci. Adv. 2020, 6, eaba1715. [CrossRef] [PubMed]

98. Oerke, E.-C. Crop Losses to Pests. J. Agric. Sci. 2006, 144, 31-43. [CrossRef]

99. Singh, R.P.; Singh, P.K.; Rutkoski, J.; Hodson, D.P.; He, X.; Jørgensen, L.N.; Hovmøller, M.S.; Huerta-Espino, J. Disease Impact on Wheat Yield Potential and Prospects of Genetic Control. Annu. Rev. Phytopathol. 2016, 54, 303-322. [CrossRef]

100. Zetzsche, H.; Friedt, W.; Ordon, F. Breeding Progress for Pathogen Resistance Is a Second Major Driver for Yield Increase in German Winter Wheat at Contrasting N Levels. Sci. Rep. 2020, 10, 20374. [CrossRef] [PubMed]

101. Savary, S.; Willocquet, L.; Pethybridge, S.J.; Esker, P.; McRoberts, N.; Nelson, A. The Global Burden of Pathogens and Pests on Major Food Crops. Nat. Ecol. Evol. 2019, 3, 430-439. [CrossRef]

102. Hossard, L.; Philibert, A.; Bertrand, M.; Colnenne-David, C.; Debaeke, P.; Munier-Jolain, N.; Jeuffroy, M.H.; Richard, G.; Makowski, D. Effects of Halving Pesticide Use on Wheat Production. Sci. Rep. 2014, 4, 4405. [CrossRef] [PubMed]

103. Christen, O. Ertrag, Ertragsstruktur und Ertragsstabilität von Weizen, Gerste und Raps in unterschiedlichen Fruchtfolgen. Pflanzenbauwissenschaften 2001, 5, 33-39.

104. Albizua, A.; Williams, A.; Hedlund, K.; Pascual, U. Crop Rotations Including Ley and Manure Can Promote Ecosystem Services in Conventional Farming Systems. Appl. Soil Ecol. 2015, 95, 54-61. [CrossRef]

105. Kehlenbeck, H.; Rajmis, S. Was Bleibt Unterm Strich. DLG Mitt. 2018, 18, 56-57.

106. Cabot, C.; Martos, S.; Llugany, M.; Gallego, B.; Tolrà, R.; Poschenrieder, C. A Role for Zinc in Plant Defense against Pathogens and Herbivores. Front. Plant. Sci. 2019, 10, 1171. [CrossRef]

107. Panpatte, D.G.; Jhala, Y.K.; Shelat, H.N.; Vyas, R.V. Pseudomonas fluorescens: A Promising Biocontrol Agent and PGPR for Sustainable Agriculture. In Microbial Inoculants in Sustainable Agricultural Productivity: Vol. 1: Research Perspectives; Singh, D.P., Singh, H.B., Prabha, R., Eds.; Springer: New Delhi, India, 2016; pp. 257-270. ISBN 978-81-322-2647-5.

108. Weiner, J.; Griepentrog, H.-W.; Kristensen, L. Suppression of Weeds by Spring Wheat Triticumaestivum Increases with Crop Density and Spatial Uniformity. J. Appl. Ecol. 2001, 38, 784-790. [CrossRef]

109. Tao, Z.; Ma, S.; Chang, X.; Wang, D.; Wang, Y.; Yang, Y.; Zhao, G.; Yang, J. Effects of Tridimensional Uniform Sowing on Water Consumption, Nitrogen Use, and Yield in Winter Wheat. Crop. J. 2019, 7, 480-493. [CrossRef]

110. Olsen, J.M.; Griepentrog, H.-W.; Nielsen, J.; Weiner, J. How Important Are Crop Spatial Pattern and Density for Weed Suppression by Spring Wheat? Weed Sci. 2012, 60, 501-509. [CrossRef]

111. Kottmann, L.; Hegewald, H.; Feike, T.; Lehnert, H.; Keilwagen, J.; Hörsten, D.; Greef, J.; Wegener, J.-K. Standraumoptimierung im Getreideanbau durch Gleichstandsaat. J. Für Kult. 2019, 71, 90-94. [CrossRef]

112. Geisseler, D.; Scow, K.M. Long-Term Effects of Mineral Fertilizers on Soil Microorganisms-A Review. Soil Biol. Biochem. 2014, 75, 54-63. [CrossRef]

113. Deppe, M.; Well, R.; Kücke, M.; Fuß, R.; Giesemann, A.; Flessa, H. Impact of CULTAN Fertilization with Ammonium Sulfate on Field Emissions of Nitrous Oxide. Agric. Ecosyst. Environ. 2016, 219, 138-151. [CrossRef] 
114. Herrmann, M.N.; Wang, Y.; Hartung, J.; Hartmann, T.; Zhang, W.; Nkebiwe, P.M.; Chen, X.; Müller, T.; Yang, H. Effects of Bioeffectors on Crop Growth and Quality Indicators: A Global Network Meta-Analysis. Agron. Sustain. Dev. 2021. (under preparation).

115. Lekfeldt, J.D.S.; Nkebiwe, P.M.; Symanczik, S.; Mäder, M.; Bar-Tal, A.; Biró, B.; Bradáčová, K.; Brecht, J.; Caniullan, P.C.; Choudhary, K.K.; et al. To BE, or Not to BE-A Meta-Analysis on the Effectiveness of Bioeffectors (BEs) on Maize, Wheat and Tomato Performance from Greenhouse to Field Scales across Europe and Israel. 2021. (under preparation).

116. Bradáčová, K.; Florea, A.S.; Bar-Tal, A.; Minz, D.; Yermiyahu, U.; Shawahna, R.; Kraut-Cohen, J.; Zolti, A.; Erel, R.; Dietel, K.; et al. Microbial Consortia versus Single-Strain Inoculants: An Advantage in PGPM-Assisted Tomato Production? Agronomy $2019,9,105$. [CrossRef]

117. Weber, J.F.; Kunz, C.; Gerhards, R. Chemical and Mechanical Weed Control in Soybean (Glycine Max). Jul. Kühn-Arch. 2016, $452,171$.

118. Pascale, A.; Vinale, F.; Manganiello, G.; Nigro, M.; Lanzuise, S.; Ruocco, M.; Marra, R.; Lombardi, N.; Woo, S.L.; Lorito, M. Trichoderma and Its Secondary Metabolites Improve Yield and Quality of Grapes. Crop. Prot. 2017, 92, 176-181. [CrossRef]

119. Giotis, C.; Markellou, E.; Theodoropoulou, A.; Kostoulas, G.; Wilcockson, S.; Leifert, C. The Effects of Different Biological Control Agents (BCAs) and Plant Defence Elicitors on Cucumber Powdery Mildew (Podosphaera Xanthii). Org. Agr. 2012, 2, 89-101. [CrossRef]

120. Barański, M.; Srednicka-Tober, D.; Volakakis, N.; Seal, C.; Sanderson, R.; Stewart, G.B.; Benbrook, C.; Biavati, B.; Markellou, E.; Giotis, C.; et al. Higher Antioxidant and Lower Cadmium Concentrations and Lower Incidence of Pesticide Residues in Organically Grown Crops: A Systematic Literature Review and Meta-Analyses. Br. J. Nutr. 2014, 112, 794-811. [CrossRef]

121. Gomiero, T. Food Quality Assessment in Organic vs. Conventional Agricultural Produce: Findings and Issues. Appl. Soil Ecol. 2018, 123, 714-728. [CrossRef]

122. Langenkämper, G.; Zörb, C.; Seifert, M.; Mäder, P.; Fretzdorff, B.; Betsche, T. Nutritional Quality of Organic and Conventional Wheat. J. Appl. Bot. Food Qual. 2006, 80, 150-154.

123. Meena, R.S.; Kumar, S.; Datta, R.; Lal, R.; Vijayakumar, V.; Brtnicky, M.; Sharma, M.P.; Yadav, G.S.; Jhariya, M.K.; Jangir, C.K.; et al. Impact of Agrochemicals on Soil Microbiota and Management: A Review. Land 2020, 9, 34. [CrossRef]

124. Zörb, C.; Steinfurth, D.; Gödde, V.; Niehaus, K.; Mühling, K.H.; Zörb, C.; Steinfurth, D.; Gödde, V.; Niehaus, K.; Mühling, K.H. Metabolite Profiling of Wheat Flag Leaf and Grains during Grain Filling Phase as Affected by Sulfur Fertilisation. Funct. Plant. Biol. 2011, 39, 156-166. [CrossRef]

125. Datta, A.; Ullah, H.; Tursun, N.; Pornprom, T.; Knezevic, S.Z.; Chauhan, B.S. Managing Weeds Using Crop Competition in Soybean (lycine $\max$ (L.) Merr.). Crop. Prot. 2017, 95, 60-68. [CrossRef]

126. Mhlanga, B.; Chauhan, B.S.; Thierfelder, C. Weed Management in Maize Using Crop Competition: A Review. Crop. Prot. 2016, 88, 28-36. [CrossRef]

127. Zörb, C.; Becker, E.; Merkt, N.; Kafka, S.; Schmidt, S.; Schmidhalter, U. Shift of Grain Protein Composition in Bread Wheat under Summer Drought Events. J. Plant. Nutr. Soil Sci. 2017, 180, 49-55. [CrossRef]

128. Leneveu-Jenvrin, C.; Charles, F.; Barba, F.J.; Remize, F. Role of Biological Control Agents and Physical Treatments in Maintaining the Quality of Fresh and Minimally-Processed Fruit and Vegetables. Crit. Rev. Food Sci. Nutr. 2020, 60, 2837-2855. [CrossRef]

129. Siroli, L.; Patrignani, F.; Serrazanetti, D.I.; Gardini, F.; Lanciotti, R. Innovative Strategies Based on the Use of Bio-Control Agents to Improve the Safety, Shelf-Life and Quality of Minimally Processed Fruits and Vegetables. Trends Food Sci. Technol. 2015, 46, 302-310. [CrossRef]

130. Lask, J.; Martínez Guajardo, A.; Weik, J.; Von Cossel, M.; Lewandowski, I.; Wagner, M. Comparative Environmental and Economic Life Cycle Assessment of Biogas Production from Perennial Wild Plant Mixtures and Maize (Zea mays L.) in Southwest Germany. GCB Bioenergy 2020. (under review). [CrossRef]

131. Hillier, J.; Brentrup, F.; Wattenbach, M.; Walter, C.; Garcia-Suarez, T.; Mila-i-Canals, L.; Smith, P. Which Cropland Greenhouse Gas Mitigation Options Give the Greatest Benefits in Different World Regions? Climate and Soil-Specific Predictions from Integrated Empirical Models. Glob. Chang. Biol. 2012, 18, 1880-1894. [CrossRef]

132. Das, S.; Ho, A.; Kim, P.J. Editorial: Role of Microbes in Climate Smart Agriculture. Front. Microbiol. 2019, 10, 2756. [CrossRef]

133. Lu, X.; Siemann, E.; He, M.; Wei, H.; Shao, X.; Ding, J. Climate Warming Increases Biological Control Agent Impact on a Non-Target Species. Ecol. Lett. 2015, 18, 48-56. [CrossRef]

134. Syafrudin, M.; Kristanti, R.A.; Yuniarto, A.; Hadibarata, T.; Rhee, J.; Al-onazi, W.A.; Algarni, T.S.; Almarri, A.H.; Al-Mohaimeed, A.M. Pesticides in Drinking Water-A Review. Int. J. Environ. Res. Public Health 2021, 18, 468. [CrossRef]

135. De Souza, R.M.; Seibert, D.; Quesada, H.B.; de Jesus Bassetti, F.; Fagundes-Klen, M.R.; Bergamasco, R. Occurrence, Impacts and General Aspects of Pesticides in Surface Water: A Review. Process. Saf. Environ. Prot. 2020, 135, 22-37. [CrossRef]

136. Singh, B.; Craswell, E. Fertilizers and Nitrate Pollution of Surface and Ground Water: An Increasingly Pervasive Global Problem. SN Appl. Sci. 2021, 3, 518. [CrossRef]

137. Colnenne-David, C.; Grandeau, G.; Jeuffroy, M.-H.; Dore, T. Ambitious Environmental and Economic Goals for the Future of Agriculture Are Unequally Achieved by Innovative Cropping Systems. Field Crop. Res. 2017, 210, 114-128. [CrossRef]

138. Ndlela, L.L.; Oberholster, P.J.; Van Wyk, J.H.; Cheng, P.H. Bacteria as Biological Control Agents of Freshwater Cyanobacteria: Is It Feasible beyond the Laboratory? Appl. Microbiol. Biotechnol. 2018, 102, 9911-9923. [CrossRef] [PubMed]

139. Kerdraon, L.; Laval, V.; Suffert, F. Microbiomes and Pathogen Survival in Crop Residues, an Ecotone Between Plant and Soil. Phytobiomes J. 2019, 3, 246-255. [CrossRef] 
140. Geiger, F.; Bengtsson, J.; Berendse, F.; Weisser, W.W.; Emmerson, M.; Morales, M.B.; Ceryngier, P.; Liira, J.; Tscharntke, T.; Winqvist, C.; et al. Persistent Negative Effects of Pesticides on Biodiversity and Biological Control Potential on European Farmland. Basic Appl. Ecol. 2010, 11, 97-105. [CrossRef]

141. Maeder, P.; Fliessbach, A.; Dubois, D.; Gunst, L.; Fried, P.; Niggli, U. Soil Fertility and Biodiversity in Organic Farming. Science 2002, 296, 1694-1697. [CrossRef] [PubMed]

142. Rodriguez-Campos, J.; Dendooven, L.; Alvarez-Bernal, D.; Contreras-Ramos, S.M. Potential of Earthworms to Accelerate Removal of Organic Contaminants from Soil: A Review. Appl. Soil Ecol. 2014, 79, 10-25. [CrossRef]

143. Rashid, M.I.; Mujawar, L.H.; Shahzad, T.; Almeelbi, T.; Ismail, I.M.I.; Oves, M. Bacteria and Fungi Can Contribute to Nutrients Bioavailability and Aggregate Formation in Degraded Soils. Microbiol. Res. 2016, 183, 26-41. [CrossRef]

144. Contreras-Cornejo, H.A.; Macías-Rodríguez, L.; del-Val, E.; Larsen, J. Ecological Functions of Trichoderma Spp. and Their Secondary Metabolites in the Rhizosphere: Interactions with Plants. FEMS Microbiol. Ecol. 2016, 92, fiw036. [CrossRef] [PubMed]

145. Halifu, S.; Deng, X.; Song, X.; Song, R. Effects of Two Trichoderma Strains on Plant Growth, Rhizosphere Soil Nutrients, and Fungal Community of Pinus Sylvestris Var. Mongolica Annual Seedlings. Forests 2019, 10, 758. [CrossRef]

146. Maji, D.; Singh, M.; Wasnik, K.; Chanotiya, C.S.; Kalra, A. The Role of a Novel Fungal Strain Trichoderma Atroviride RVF3 in Improving Humic Acid Content in Mature Compost and Vermicompost via Ligninolytic and Celluloxylanolytic Activities. J. Appl. Microbiol. 2015, 119, 1584-1596. [CrossRef] [PubMed]

147. Mitra, D.; Anđelković, S.; Panneerselvam, P.; Senapati, A.; Vasić, T.; Ganeshamurthy, A.N.; Chauhan, M.; Uniyal, N.; Mahakur, B.; Radha, T.K. Phosphate-Solubilizing Microbes and Biocontrol Agent for Plant Nutrition and Protection: Current Perspective. Commun. Soil Sci. Plant. Anal. 2020, 51, 645-657. [CrossRef]

148. Matsumoto, L.S.; dos Santos, I.M.O.; Barazetti, A.R.; Simões, G.C.; Farias, T.N.; Andrade, G. Effects of Biological Control Agents on Arbuscular Mycorrhiza Fungi Rhizophagus Clarus in Soybean Rhizosphere. Agron. Sci. Biotechnol. 2017, 3, 29. [CrossRef]

149. Ahmed, E.; Holmström, S.J.M. Siderophores in Environmental Research: Roles and Applications. Microb. Biotechnol. 2014, 7, 196-208. [CrossRef]

150. Sivasakthi, S.; Usharani, G.; Saranraj, P. Biocontrol Potentiality of Plant Growth Promoting Bacteria (PGPR)-Pseudomonas Fluorescens and Bacillus Subtilis: A Review. AJAR 2014, 9, 1265-1277. [CrossRef]

151. Catarino, R.; Bretagnolle, V.; Perrot, T.; Vialloux, F.; Gaba, S. Bee Pollination Outperforms Pesticides for Oilseed Crop Production and Profitability. Proc. R. Soc. B Biol. Sci. 2019, 286, 20191550. [CrossRef]

152. Potts, S.G.; Biesmeijer, J.C.; Kremen, C.; Neumann, P.; Schweiger, O.; Kunin, W.E. Global Pollinator Declines: Trends, Impacts and Drivers. Trends Ecol. Evol. 2010, 25, 345-353. [CrossRef] [PubMed]

153. Marja, R.; Kleijn, D.; Tscharntke, T.; Klein, A.-M.; Frank, T.; Batáry, P. Effectiveness of Agri-Environmental Management on Pollinators Is Moderated More by Ecological Contrast than by Landscape Structure or Land-Use Intensity. Ecol. Lett. 2019, 22, 1493-1500. [CrossRef]

154. Peñuelas, J.; Farré-Armengol, G.; Llusia, J.; Gargallo-Garriga, A.; Rico, L.; Sardans, J.; Terradas, J.; Filella, I. Removal of Floral Microbiota Reduces Floral Terpene Emissions. Sci. Rep. 2014, 4, 6727. [CrossRef]

155. Pallutt, B. 30 Jahre Dauerfeldversuche zum Pflanzenschutz. JFK 2010, 62, 230-237. [CrossRef]

156. Dierauer, H.U.; Stöppler-Zimmer, H. Unkrautregulierung Ohne Chemie; Verlag Ulmer: Stuttgart, Germany, 2014; ISBN 3-8001-4096-9.

157. Zhou, M.; Liu, C.; Wang, J.; Meng, Q.; Yuan, Y.; Ma, X.; Liu, X.; Zhu, Y.; Ding, G.; Zhang, J.; et al. Soil Aggregates Stability and Storage of Soil Organic Carbon Respond to Cropping Systems on Black Soils of Northeast China. Sci. Rep. 2020, 10, 265. [CrossRef]

158. Harding, D.P.; Raizada, M.N. Controlling Weeds with Fungi, Bacteria and Viruses: A Review. Front. Plant. Sci. 2015, 6, 659. [CrossRef]

159. Raymaekers, K.; Ponet, L.; Holtappels, D.; Berckmans, B.; Cammue, B.P.A. Screening for Novel Biocontrol Agents Applicable in Plant Disease Management-A Review. Biol. Control. 2020, 144, 104240. [CrossRef]

160. Tscharntke, T.; Klein, A.M.; Kruess, A.; Steffan-Dewenter, I.; Thies, C. Landscape Perspectives on Agricultural Intensification and Biodiversity-Ecosystem Service Management. Ecol. Lett. 2005, 8, 857-874. [CrossRef]

161. Krauss, J.; Gallenberger, I.; Steffan-Dewenter, I. Decreased Functional Diversity and Biological Pest Control in Conventional Compared to Organic Crop Fields. PLoS ONE 2011, 6, e19502. [CrossRef]

162. El-Wakeil, N.; Gaafar, N.; Sallam, A.; Volkmar, C. Side Effects of Insecticides on Natural Enemies and Possibility of Their Integration in Plant Protection Strategies; IntechOpen: London, UK, 2013; ISBN 978-953-51-0958-7.

163. Garratt, M.P.D.; Wright, D.J.; Leather, S.R. The Effects of Farming System and Fertilisers on Pests and Natural Enemies: A Synthesis of Current Research. Agric. Ecosyst. Environ. 2011, 141, 261-270. [CrossRef]

164. Ingwersen, J.; Högy, P.; Wizemann, H.D.; Warrach-Sagi, K.; Streck, T. Coupling the Land Surface Model Noah-MP with the Generic Crop Growth Model Gecros: Model Description, Calibration and Validation. Agric. For. Meteorol. 2018, 262, 322-339. [CrossRef]

165. Goudriaan, J. Simulation of Micrometeorology of Crops, Some Methods and Their Problems, and a Few Results. Agric. For. Meteorol. 1989, 47, 239-258. [CrossRef]

166. Vidal, T.; Boixel, A.-L.; Durand, B.; de Vallavieille-Pope, C.; Huber, L.; Saint-Jean, S. Reduction of Fungal Disease Spread in Cultivar Mixtures: Impact of Canopy Architecture on Rain-Splash Dispersal and on Crop Microclimate. Agric. For. Meteorol. 2017, 246, 154-161. [CrossRef] 
167. El-Hasan, A.; Buchenauer, H. Actions of 6-Pentyl-Alpha-Pyrone in Controlling Seedling Blight Incited by Fusarium Moniliforme and Inducing Defence Responses in Maize. J. Phytopathol. 2009, 157, 697-707. [CrossRef]

168. Benjamin, E.O.; Wesseler, J.H.H. A Socioeconomic Analysis of Biocontrol in Integrated Pest Management: A Review of the Effects of Uncertainty, Irreversibility and Flexibility. NJAS Wagening. J. Life Sci. 2016, 77, 53-60. [CrossRef]

169. Goulson, D. Pesticides Linked to Bird Declines. Nature 2014, 511, 295-296. [CrossRef] [PubMed]

170. Niggli, U.; Riedel, J.; Brühl, C.; Liess, M.; Schulz, R.; Altenburger, R.; Märländer, B.; Bokelmann, W.; Heß, J.; Reineke, A.; et al. Pflanzenschutz und Biodiversität in Agrarökosystemen. Ber. Über Landwirtsch. Z. Für Agrarpolit. Und Landwirtsch. 2020, 98, 1-39. [CrossRef]

171. Huth, E.; Paltrinieri, S.; Thiele, J. Bioenergy and Its Effects on Landscape Aesthetics-A Survey Contrasting Conventional and Wild Crop Biomass Production. Biomass Bioenergy 2019, 122, 313-321. [CrossRef]

172. Reiser, D.; Martín-López, J.M.; Memic, E.; Vázquez-Arellano, M.; Brandner, S.; Griepentrog, H.W. 3D Imaging with a Sonar Sensor and an Automated 3-Axes Frame for Selective Spraying in Controlled Conditions. J. Imaging 2017, 3, 9. [CrossRef]

173. Vázquez-Arellano, M.; Reiser, D.; Paraforos, D.S.; Garrido-Izard, M.; Burce, M.E.C.; Griepentrog, H.W. 3-D Reconstruction of Maize Plants Using a Time-of-Flight Camera. Comput. Electron. Agric. 2018, 145, 235-247. [CrossRef]

174. Gerhards, R.; Kollenda, B.; Machleb, J.; Möller, K.; Butz, A.; Reiser, D.; Griegentrog, H.-W. Camera-Guided Weed Hoeing in Winter Cereals with Narrow Row Distance. Gesunde Pflanz. 2020, 72, 403-411. [CrossRef]

175. Munz, S.; Reiser, D. Approach for Image-Based Semantic Segmentation of Canopy Cover in Pea-Oat Intercropping. Agriculture 2020, 10, 354. [CrossRef]

176. Mahlein, A.-K. Plant Disease Detection by Imaging Sensors-Parallels and Specific Demands for Precision Agriculture and Plant Phenotyping. Plant. Dis. 2016, 100, 241-251. [CrossRef] [PubMed]

177. Thomas, S.; Kuska, M.T.; Bohnenkamp, D.; Brugger, A.; Alisaac, E.; Wahabzada, M.; Behmann, J.; Mahlein, A.-K. Benefits of Hyperspectral Imaging for Plant Disease Detection and Plant Protection: A Technical Perspective. J. Plant. Dis. Prot. 2018, 125, 5-20. [CrossRef]

178. Wahabzada, M.; Mahlein, A.-K.; Bauckhage, C.; Steiner, U.; Oerke, E.-C.; Kersting, K. Metro Maps of Plant Disease DynamicsAutomated Mining of Differences Using Hyperspectral Images. PLoS ONE 2015, 10, e0116902. [CrossRef]

179. Thomas, S.; Wahabzada, M.; Kuska, M.T.; Rascher, U.; Mahlein, A.-K.; Thomas, S.; Wahabzada, M.; Kuska, M.T.; Rascher, U.; Mahlein, A.-K. Observation of Plant-Pathogen Interaction by Simultaneous Hyperspectral Imaging Reflection and Transmission Measurements. Funct. Plant. Biol. 2016, 44, 23-34. [CrossRef]

180. Tsouros, D.C.; Bibi, S.; Sarigiannidis, P.G. A Review on UAV-Based Applications for Precision Agriculture. Information 2019, 10, 349. [CrossRef]

181. Watson, C.A.; Reckling, M.; Preissel, S.; Bachinger, J.; Bergkvist, G.; Kuhlman, T.; Lindström, K.; Nemecek, T.; Topp, C.F.E.; Vanhatalo, A.; et al. Chapter Four-Grain Legume Production and Use in European Agricultural Systems. In Advances in Agronomy; Sparks, D.L., Ed.; Academic Press: Cambridge, MA, USA, 2017; Volume 144, pp. 235-303.

182. Brankatschk, G.; Finkbeiner, M. Crop Rotations and Crop Residues Are Relevant Parameters for Agricultural Carbon Footprints. Agron. Sustain. Dev. 2017, 37, 58. [CrossRef]

183. Kolbe, H. Fruchtfolgegestaltung im ökologischen und extensiven Landbau: Bewertung von Vorfruchtwirkungen. Pflanzenbauwissenschaften 2006, 10, 82-89.

184. Bundessortenamt. Beschreibende Sortenliste Getreide, Mais Öl- Und Faserpflanzen Leguminosen Rüben Zwischenfrüchte 2020; Bundessortenamt: Hannover, Germany, 2020.

185. Miedaner, T.; Juroszek, P. Climate Change Will Influence Disease Resistance Breeding in Wheat in Northwestern Europe. Theor. Appl. Genet. 2021, 134, 1771-1785. [CrossRef] [PubMed]

186. Tian, J.; Xu, G.; Yuan, M. Towards Engineering Broad-Spectrum Disease-Resistant Crops. Trends Plant. Sci. 2020, 25, 424-427. [CrossRef]

187. Van Esse, H.P.; Reuber, T.L.; van der Does, D. Genetic Modification to Improve Disease Resistance in Crops. New Phytol. 2020, 225, 70-86. [CrossRef]

188. Langner, T.; Kamoun, S.; Belhaj, K. CRISPR Crops: Plant Genome Editing Toward Disease Resistance. Annu. Rev. Phytopathol. 2018, 56, 479-512. [CrossRef]

189. Eom, J.-S.; Luo, D.; Atienza-Grande, G.; Yang, J.; Ji, C.; Thi Luu, V.; Huguet-Tapia, J.C.; Char, S.N.; Liu, B.; Nguyen, H.; et al. Diagnostic Kit for Rice Blight Resistance. Nat. Biotechnol. 2019, 37, 1372-1379. [CrossRef]

190. Oliva, R.; Ji, C.; Atienza-Grande, G.; Huguet-Tapia, J.C.; Perez-Quintero, A.; Li, T.; Eom, J.-S.; Li, C.; Nguyen, H.; Liu, B.; et al. Broad-Spectrum Resistance to Bacterial Blight in Rice Using Genome Editing. Nat. Biotechnol. 2019, 37, 1344-1350. [CrossRef]

191. Griepentrog, H.W. Längsverteilung von Sämaschinen und ihre Wirkung auf Standfläche und Ertrag bei Raps. Agrartech. Forsch. 1995, 1. Available online: https:/ / docplayer.org/70215040-Laengsverteilung-von-saemaschinen-und-ihre-wirkung-aufstandflaeche-und-ertrag-bei-raps.html (accessed on 25 August 2021).

192. Boulard, T.; Roy, J.-C.; Pouillard, J.-B.; Fatnassi, H.; Grisey, A. Modelling of Micrometeorology, Canopy Transpiration and Photosynthesis in a Closed Greenhouse Using Computational Fluid Dynamics. Biosyst. Eng. 2017, 158, 110-133. [CrossRef]

193. Sultan, S.E. Phenotypic Plasticity for Plant Development, Function and Life History. Trends Plant. Sci. 2000, 5, 537-542. [CrossRef]

194. Bongers, F.J.; Pierik, R.; Anten, N.P.R.; Evers, J.B. Subtle Variation in Shade Avoidance Responses May Have Profound Consequences for Plant Competitiveness. Ann. Bot. 2018, 121, 863-873. [CrossRef] [PubMed] 
195. Zhu, J.; Vos, J.; van der Werf, W.; van der Putten, P.E.L.; Evers, J.B. Early Competition Shapes Maize Whole-Plant Development in Mixed Stands. J. Exp. Bot. 2014, 65, 641-653. [CrossRef] [PubMed]

196. Evers, J.B.; Bastiaans, L. Quantifying the Effect of Crop Spatial Arrangement on Weed Suppression Using Functional-Structural Plant Modelling. J. Plant. Res. 2016, 129, 339-351. [CrossRef]

197. Bradáčová, K.; Weber, N.F.; Morad-Talab, N.; Asim, M.; Imran, M.; Weinmann, M.; Neumann, G. Micronutrients (Zn/Mn), Seaweed Extracts, and Plant Growth-Promoting Bacteria as Cold-Stress Protectants in Maize. Chem. Biol. Technol. Agric. 2016, 3, 19. [CrossRef]

198. Datnoff, L.E.; Elmer, W.H.; Huber, D.M. Mineral Nutrition and Plant Disease. Amer Phytopathological Society: St. Paul, MN, USA, 2007.

199. Imran, M.; Mahmood, A.; Römheld, V.; Neumann, G. Nutrient Seed Priming Improves Seedling Development of Maize Exposed to Low Root Zone Temperatures during Early Growth. Eur. J. Agron. 2013, 49, 141-148. [CrossRef]

200. Huber, D.M.; Watson, R.D. Nitrogen Form and Plant Disease. Annu. Rev. Phytopathol. 1974, 12, 139-165. [CrossRef]

201. Sun, R.-C. Lignin Source and Structural Characterization. ChemSusChem 2020, 13, 4385-4393. [CrossRef]

202. Coskun, D.; Deshmukh, R.; Sonah, H.; Menzies, J.G.; Reynolds, O.; Ma, J.F.; Kronzucker, H.J.; Bélanger, R.R. The Controversies of Silicon's Role in Plant Biology. New Phytol. 2019, 221, 67-85. [CrossRef]

203. Datnoff, E.L.; Rodrigues, A.F. Highlights and Prospects for Using Silicon in the Future. In Silicon and Plant Diseases; Rodrigues, F.A., Datnoff, L.E., Eds.; Springer International Publishing: Cham, Switzerland, 2015; pp. 139-145. ISBN 978-3-319-22930-0.

204. Huber, D.M.; Wilhelm, N.S. The Role of Manganese in Resistance to Plant Diseases. In Manganese in Soils and Plants, Proceedings of the International Symposium on 'Manganese in Soils and Plants' held at the Waite Agricultural Research Institute, The University of Adelaide, Glen Osmond, South Australia, 22-26 August 1988; Graham, R.D., Hannam, R.J., Uren, N.C., Eds.; Developments in Plant and Soil Sciences; Springer: Dordrecht, The Netherlands, 1988; pp. 155-173. ISBN 978-94-009-2817-6.

205. Lutman, P.J.W.; Moss, S.R.; Cook, S.; Welham, S.J. A Review of the Effects of Crop Agronomy on the Management of Alopecurus Myosuroides. Weed Res. 2013, 53, 299-313. [CrossRef]

206. Hurle, K. Integrated Management of Grass Weeds in Arable Crops. In Proceedings of the International Conference, British Crop Protection Council, Brighton, UK, 22-25 November 1993; pp. 81-88.

207. Riemens, M.; Weide, R.V.D.; Bleeker, P.; Lotz, L. Effect of Stale Seedbed Preparations and Subsequent Weed Control in Lettuce (Cv. Iceboll) on Weed Densities. Weed Res. 2007, 47, 149-156. [CrossRef]

208. Melander, B.; Cirujeda, A.; Jørgensen, M.H. Effects of Inter-Row Hoeing and Fertilizer Placement on Weed Growth and Yield of Winter Wheat. Weed Res. 2003, 43, 428-438. [CrossRef]

209. Conrath, U.; Beckers, G.J.M.; Flors, V.; García-Agustín, P.; Jakab, G.; Mauch, F.; Newman, M.-A.; Pieterse, C.M.J.; Poinssot, B.; Pozo, M.J.; et al. Priming: Getting Ready for Battle. MPMI 2006, 19, 1062-1071. [CrossRef] [PubMed]

210. Kunz, J.; Löffler, G.; Bauhus, J. Minor European Broadleaved Tree Species Are More Drought-Tolerant than Fagus Sylvatica but Not More Tolerant than Quercus Petraea. For. Ecol. Manag. 2018, 414, 15-27. [CrossRef]

211. Fernández, F.G.; White, C. No-Till and Strip-Till Corn Production with Broadcast and Subsurface-Band Phosphorus and Potassium. Agron. J. 2012, 104, 996-1005. [CrossRef]

212. Kuska, M.; Wahabzada, M.; Leucker, M.; Dehne, H.-W.; Kersting, K.; Oerke, E.-C.; Steiner, U.; Mahlein, A.-K. Hyperspectral Phenotyping on the Microscopic Scale: Towards Automated Characterization of Plant-Pathogen Interactions. Plant. Methods 2015, 11, 28. [CrossRef]

213. Kuska, M.T.; Brugger, A.; Thomas, S.; Wahabzada, M.; Kersting, K.; Oerke, E.-C.; Steiner, U.; Mahlein, A.-K. Spectral Patterns Reveal Early Resistance Reactions of Barley against Blumeria graminis f. Sp. Hordei. Phytopathology 2017, 107, 1388-1398. [CrossRef]

214. Leucker, M.; Mahlein, A.-K.; Steiner, U.; Oerke, E.-C. Improvement of Lesion Phenotyping in Cercospora Beticola-Sugar Beet Interaction by Hyperspectral Imaging. Phytopathology 2015, 106, 177-184. [CrossRef] [PubMed]

215. Scheu, S. Effects of Earthworms on Plant Growth: Patterns and Perspectives: The 7th International Symposium on Earthworm Ecology Cardiff Wales 2002. Pedobiologia 2003, 47, 846-856. [CrossRef]

216. Stott, D.E.; Kennedy, A.C.; Cambardella, C.A. Impact of Soil Organisms and Organic Matter on Soil Structure: \#. In Soil Quality and Soil Erosion; CRC Press: Boca Raton, FL, USA, 1999; ISBN 978-0-203-73926-6.

217. Kumar, A.; Verma, J.P. Does Plant-Microbe Interaction Confer Stress Tolerance in Plants: A Review? Microbiol. Res. 2018, 207, 41-52. [CrossRef]

218. Hallama, M.; Pekrun, C.; Lambers, H.; Kandeler, E. Hidden Miners-The Roles of Cover Crops and Soil Microorganisms in Phosphorus Cycling through Agroecosystems. Plant. Soil 2019, 434, 7-45. [CrossRef]

219. Hallama, M.; Pekrun, C.; Pilz, S.; Jarosch, K.A.; Frąc, M.; Uksa, M.; Marhan, S.; Kandeler, E. Interactions between Cover Crops and Soil Microorganisms Increase Phosphorus Availability in Conservation Agriculture. Plant. Soil 2021, 463, 307-328. [CrossRef]

220. Pelosi, C.; Barot, S.; Capowiez, Y.; Hedde, M.; Vandenbulcke, F. Pesticides and Earthworms. A Review. Agron. Sustain. Dev. 2014, 34, 199-228. [CrossRef]

221. Stukenbrock, E.H.; McDonald, B.A. The Origins of Plant Pathogens in Agro-Ecosystems. Annu. Rev. Phytopathol. 2008, 46, 75-100. [CrossRef]

222. Hubbard, A.; Lewis, C.M.; Yoshida, K.; Ramirez-Gonzalez, R.H.; de Vallavieille-Pope, C.; Thomas, J.; Kamoun, S.; Bayles, R.; Uauy, C.; Saunders, D.G. Field Pathogenomics Reveals the Emergence of a Diverse Wheat Yellow Rust Population. Genome Biol. 2015, 16, 23. [CrossRef] [PubMed] 
223. Bueno-Sancho, V.; Persoons, A.; Hubbard, A.; Cabrera-Quio, L.E.; Lewis, C.M.; Corredor-Moreno, P.; Bunting, D.C.E.; Ali, S.; Chng, S.; Hodson, D.P.; et al. Pathogenomic Analysis of Wheat Yellow Rust Lineages Detects Seasonal Variation and Host Specificity. Genome Biol. Evol. 2017, 9, 3282-3296. [CrossRef]

224. Zebisch, M. Modellierung der Auswirkungen von Landnutzungsänderungen auf Landschaftsmuster und Biodiversität. Ph.D. Thesis, Technische Universität Berlin, Berlin, Germany, 2004. [CrossRef]

225. Lázaro, A.; Alomar, D. Landscape Heterogeneity Increases the Spatial Stability of Pollination Services to Almond Trees through the Stability of Pollinator Visits. Agric. Ecosyst. Environ. 2019, 279, 149-155. [CrossRef]

226. Thies, C.; Tscharntke, T. Landscape Structure and Biological Control in Agroecosystems. Science 1999, 285, 893-895. [CrossRef]

227. Sirami, C.; Gross, N.; Baillod, A.B.; Bertrand, C.; Carrié, R.; Hass, A.; Henckel, L.; Miguet, P.; Vuillot, C.; Alignier, A.; et al. Increasing Crop Heterogeneity Enhances Multitrophic Diversity across Agricultural Regions. Proc. Natl. Acad. Sci. USA 2019, 116, 16442-16447. [CrossRef] [PubMed]

228. Stark, A.; Wetzel, T. Fliegen Der Gattung Platypalpus (Diptera, Empididae)-Bisher Wenig Beachtete Prädatoren Im Getreidebestand. J. Appl. Entomol. 1987, 103, 1-14. [CrossRef]

229. Weber, G.; Franzen, J.; Büchs, W. Beneficial Diptera in Field Crops with Different Inputs of Pesticides and Fertilizers. Biol. Agric. Hortic. 1997, 15, 109-122. [CrossRef]

230. Stark, A. Zum Beutespektrum Und Jagdverhalten von Fliegen Der Gattung Platypalpus (Empidoidea, Hybotidae). Studia Dipterol. 1994, 1, 49-74.

231. Willocquet, L.; Meza, W.R.; Dumont, B.; Klocke, B.; Feike, T.; Kersebaum, K.C.; Meriggi, P.; Rossi, V.; Ficke, A.; Djurle, A.; et al. An Outlook on Wheat Health in Europe from a Network of Field Experiments. Crop. Prot. 2021, 139, 105335. [CrossRef]

232. Röll, G.; Batchelor, W.D.; Castro, A.C.; Simón, M.R.; Graeff-Hönninger, S. Development and Evaluation of a Leaf Disease Damage Extension in Cropsim-CERES Wheat. Agronomy 2019, 9, 120. [CrossRef]

233. Obata, T.; Fernie, A.R. The Use of Metabolomics to Dissect Plant Responses to Abiotic Stresses. Cell. Mol. Life Sci. 2012, 69, 3225-3243. [CrossRef]

234. Lechenet, M.; Dessaint, F.; Py, G.; Makowski, D.; Munier-Jolain, N. Reducing Pesticide Use While Preserving Crop Productivity and Profitability on Arable Farms. Nat. Plants 2017, 3, 17008. [CrossRef]

235. Dabbert, S.; Braun, J. Landwirtschaftliche Betriebslehre. Grundwissen Bachelor, 3rd ed.; Verlag Eugen Ulmer: Stuttgart, Germany, 2012; ISBN 978-3-8252-3819-3.

236. Hardaker, J.B.; Huirne, R.B.M.; Anderson, J.R.; Lien, G. (Eds.) Coping with Risk in Agriculture, 2nd ed.; CABI: Wallingford, UK, 2004; ISBN 978-0-85199-831-2.

237. Mußhoff, O.; Hirschhauer, N. Modernes Agrarmanagement Betriebswirtschaftliche Analyse- Und Planungsverfahren, 2nd ed.; Vahlen Franz GmbH: München, Germany, 2011; ISBN 978-3-8006-3827-7.

238. Bhattacharya, S. Deadly New Wheat Disease Threatens Europe's Crops. Nature 2017, 542, 145-146. [CrossRef]

239. Heap, I. International Survey of Herbicide Resistant Weeds. Available online: http://www.weedscience.org/Home.aspx (accessed on 1 October 2018).

240. North, D.C. Institutions, Institutional Change and Economic Performance; Cambridge University Press: Cambridge, UK, 1990.

241. Ostrom, E. Governing the Commons: The Evolution of Institutions for Collective Action; Cambridge University Press: Cambridge, UK, 1990.

242. European Commission. Ernährung Und Landwirtschaft Der Zukunft; European Commission: Brussels, Belgium, 2017.

243. Gutsche, V. Managementstrategien des Pflanzenschutzes der Zukunft im Focus von Umweltverträglichkeit und Effizienz. J. Für Kult. 2012, 64, 325-341.

244. Böl, G.-F.; Epp, A.; Michalski, B. Pflanzenschutzmittelrückstände in Lebensmitteln, Die Wahrnehmung der deutschen Bevölkerung. 57. Deutsche Pflanzenschutztagung: 6-9 September 2010; Humboldt-Universität zu Berlin; Kurzfassungen der Beiträge 2010. Available online: https://www.kulturkaufhaus.de/de/detail/ISBN-9783938163603/Epp-A./Pflanzenschutzmittel-R\%C3\%BCckst\% C3\%A4nde-in-Lebensmitteln (accessed on 25 August 2021).

245. BfR. Pflanzenschutzmittel und -Rückstände in Lebensmitteln; Analyse der Medienberichterstattung PlantMedia; Bundesinstitut für Risikobewertung: Berlin, Germany, 2013.

246. Bruhn, C.M.; Diaz-Knauf, K.; Feldman, N.; Harwood, J.; Ho, G.; Ivans, E.; Kubin, L.; Lamp, C.; Marshall, M.; Osaki, S.; et al. Consumer Food Safety Concerns and Interest in Pesticide-Related Information. J. Food Saf. 1991, 12, 253-262. [CrossRef]

247. Huang, C.L. Consumer Preferences and Attitudes towards Organically Grown Produce. Eur. Rev. Agric. Econ. 1996, $23,331-342$. [CrossRef]

248. Koch, S.; Epp, A.; Lohmann, M.; Böl, G.-F. Pesticide Residues in Food: Attitudes, Beliefs, and Misconceptions among Conventional and Organic Consumers. J. Food Prot. 2017, 80, 2083-2089. [CrossRef]

249. Misra, S.; Huang, C.L.; Ott, S.L. Georgia Consumers' Preference for Organically Grown Fresh Produce. J. Agribus. 1991, 9, 53-63.

250. Magnusson, M.K.; Arvola, A.; Koivisto Hursti, U.; Åberg, L.; Sjödén, P. Attitudes towards Organic Foods among Swedish Consumers. Br. Food J. 2001, 103, 209-227. [CrossRef]

251. Hemmerling, S.; Hamm, U.; Spiller, A. Consumption Behaviour Regarding Organic Food from a Marketing Perspective-A Literature Review. Org. Agr. 2015, 5, 277-313. [CrossRef]

252. Spiller, A.; Nitzko, S. Welchen Mehrwert Haben Agrarprodukte Ohne CPSM, Die Dennoch Nicht Öko Sind? Landinfo 2019, 2 , $15-18$. 
253. Cranfield, J.A.L.; Magnusson, E. Canadian Consumer's Willingness-To-Pay for Pesticide Free Food Products: An Ordered Probit Analysis. Int. Food Agribus. Manag. Rev. 2003, 6, 1-18.

254. Weaver, R.D.; Evans, D.J.; Luloff, A.E. Pesticide Use in Tomato Production: Consumer Concerns and Willingness-to-Pay. Agribusiness 1992, 8, 131-142. [CrossRef]

255. Boccaletti, S.; Nardella, M. Consumer Willingness to Pay for Pesticide-Free Fresh Fruit and Vegetables in Italy. Int. Food Agribus. Manag. Rev. 2000, 3, 297-310. [CrossRef]

256. Román, S.; Sánchez-Siles, L.M.; Siegrist, M. The Importance of Food Naturalness for Consumers: Results of a Systematic Review. Trends Food Sci. Technol. 2017, 67, 44-57. [CrossRef]

257. Keller, R. Diskursforschung: Eine Einführung für SozialwissenschaftlerInnen, 4th ed.; Qualitative Sozialforschung; Springer: Berlin/Heidelberg, Germany, 2011; ISBN 978-3-531-17352-8.

258. Paltridge, B. Discourse Analysis An. Introduction, 2nd ed.; Bloomsbury Publishing Plc: New York, NY, USA, 2012; ISBN 978-1-4411-6762-0.

259. Dijkman, T.J.; Birkved, M.; Hauschild, M.Z. PestLCI 2.0: A Second Generation Model for Estimating Emissions of Pesticides from Arable Land in LCA. Int. J. Life Cycle Assess. 2012, 17, 973-986. [CrossRef]

260. Von Cossel, M. Renewable Energy from Wildflowers-Perennial Wild Plant Mixtures as a Social-Ecologically Sustainable Biomass Supply System. Adv. Sustain. Syst. 2020, 4, 2000037. [CrossRef]

261. Von Cossel, M.; Winkler, B.; Mangold, A.; Lask, J.; Wagner, M.; Lewandowski, I.; Elbersen, B.; van Eupen, M.; Mantel, S.; Kiesel, A. Bridging the Gap between Biofuels and Biodiversity through Monetizing Environmental Services of Miscanthus Cultivation. Earth's Future 2020, 8, e2020EF001478. [CrossRef]

262. Janusch, C.; Lewin, E.F.; Battaglia, M.L.; Rezaei-Chiyaneh, E.; Von Cossel, M. Flower-Power in the Bioenergy Sector-A Review on Second Generation Biofuel from Perennial Wild Plant Mixtures. Renew. Sustain. Energy Rev. 2021, 147, 111257. [CrossRef]

263. Nemecek, T.; Dubois, D.; Huguenin-Elie, O.; Gaillard, G. Life Cycle Assessment of Swiss Farming Systems: I. Integrated and Organic Farming. Agric. Syst. 2011, 104, 217-232. [CrossRef]

264. Meyer, F.; Wagner, M.; Lewandowski, I. Optimizing GHG Emission and Energy-Saving Performance of Miscanthus-Based Value Chains. Biomass Conv. Bioref. 2017, 7, 139-152. [CrossRef]

265. Pishgar-Komleh, S.H.; Sefeedpari, P.; Pelletier, N.; Brandão, M. Life cycle assessment methodology for agriculture: Some considerations for best practices. In Assessing the Environmental Impact of Agriculture; Weidema, B.P., Ed.; Burleigh Dodds Science Publishing Limited: Cambridge, UK, 2019; ISBN 978-1-78676-228-3.

266. Schmidt, T.; Fernando, A.L.; Monti, A.; Rettenmaier, N. Life Cycle Assessment of Bioenergy and Bio-Based Products from Perennial Grasses Cultivated on Marginal Land in the Mediterranean Region. Bioenerg. Res. 2015, 8, 1548-1561. [CrossRef]

267. Searchinger, T.D.; Beringer, T.; Holtsmark, B.; Kammen, D.M.; Lambin, E.F.; Lucht, W.; Raven, P.; Ypersele, J.-P. Europe's Renewable Energy Directive Poised to Harm Global Forests. Nat. Commun. 2018, 9, 3741. [CrossRef] [PubMed]

268. Ceballos, G.; Ehrlich, P.R.; Barnosky, A.D.; García, A.; Pringle, R.M.; Palmer, T.M. Accelerated Modern Human-Induced Species Losses: Entering the Sixth Mass Extinction. Sci. Adv. 2015, 1, e1400253. [CrossRef] [PubMed]

269. Von Cossel, M.; Wagner, M.; Lask, J.; Magenau, E.; Bauerle, A.; Von Cossel, V.; Warrach-Sagi, K.; Elbersen, B.; Staritsky, I.; van Eupen, M.; et al. Prospects of Bioenergy Cropping Systems for a More Social-Ecologically Sound Bioeconomy. Agronomy 2019, 9, 605. [CrossRef]

270. Goglio, P.; Brankatschk, G.; Knudsen, M.T.; Williams, A.G.; Nemecek, T. Addressing Crop Interactions within Cropping Systems in LCA. Int. J. Life Cycle Assess. 2018, 23, 1735-1743. [CrossRef]

271. Costa, M.P.; Chadwick, D.; Saget, S.; Rees, R.M.; Williams, M.; Styles, D. Representing Crop Rotations in Life Cycle Assessment: A Review of Legume LCA Studies. Int. J. Life Cycle Assess. 2020, 25, 1942-1956. [CrossRef]

272. Calvet, C.; Napoléone, C.; Salles, J.-M. The Biodiversity Offsetting Dilemma: Between Economic Rationales and Ecological Dynamics. Sustainability 2015, 7, 7357-7378. [CrossRef]

273. Wagner, M.; Lewandowski, I. Relevance of Environmental Impact Categories for Perennial Biomass Production. Gcb Bioenergy 2017, 9, 215-228. [CrossRef]

274. Alejandre, E.M.; van Bodegom, P.M.; Guinée, J.B. Towards an Optimal Coverage of Ecosystem Services in LCA. J. Clean. Prod. 2019, 231, 714-722. [CrossRef]

275. Bos, U.; Horn, R.; Beck, T.; Lindner, J.P.; Fischer, M. LANCA ${ }^{\circledR}$ —Characterization Factors for Life Cycle Impact Assessment; Version 2.0; Fraunhofer-Institut für Bauphysik: Stuttgart, Germany, 2016.

276. Chaudhary, A.; Brooks, T.M. Land Use Intensity-Specific Global Characterization Factors to Assess Product Biodiversity Footprints. Environ. Sci. Technol. 2018, 52, 5094-5104. [CrossRef] [PubMed]

277. Crenna, E.; Marques, A.; La Notte, A.; Sala, S. Biodiversity Assessment of Value Chains: State of the Art and Emerging Challenges. Environ. Sci. Technol. 2020, 54, 9715-9728. [CrossRef] 